\title{
Coronaviridae: Infectious Bronchitis Virus
}

\author{
Ahmed S. Abdel-Moneim
}

\subsection{History}

Infectious bronchitis was first reported in 1931 who had observed the disease in North Dakota in the spring of 1930 (Schalk and Hawn 1931), and in 1936, the virus etiology was established (Beach and Schalm 1936). Initially, IBV was recognized as primarily a disease of young chickens; however it was later recorded to be common in semi-mature and laying flocks. Other manifestations of IBV include decline in egg production in laying flocks noted following the typical respiratory disease in the 1940s, kidney lesions observed in the 1960s (Cavanagh and Gelb 2008), enteric lesions observed in 1985, and more recently proventriculus affection in 1998.

\subsection{Classification}

IBV is a large, enveloped, positive-stranded RNA gammacoronavirus that is related to the family Coronaviridae, subfamily Coronavirinae, and within the order Nidovirales (Table 5.1). The coronaviruses possess the largest RNA genome of all RNA viruses and replicate by a unique mechanism associated with a multiple subgenomic nested set of mRNAs and high frequency of recombination. The subfamily Coronavirinae contains four distinct genera: Alphacoronavirus, Betacoronavirus, Deltacoronavirus, and Gammacoronavirus. To date, viruses of Alphacoronavirus and Betacoronavirus have been isolated from mammals, while deltacoronaviruses have been isolated from birds and pigs (Table 5.1) (Woo et al. 2012). Meanwhile, gammacoronaviruses are

\footnotetext{
A.S. Abdel-Moneim

Department of Microbiology (Virology Division), College of Medicine, Taif University, Al-Taif 21944, Saudi Arabia

Department of Virology, Faculty of Veterinary Medicine, Beni-Suef University,

Beni-Suef 62511, Egypt

e-mail: asa@bsu.edu.eg 
Table 5.1 Taxonomy of coronaviruses

\begin{tabular}{|c|c|}
\hline \multicolumn{2}{|l|}{$\begin{array}{l}\text { Order: Nidovirales } \\
\text { Family: Coronaviridae } \\
\text { Subfamily: Coronavirinae }\end{array}$} \\
\hline \multirow[t]{2}{*}{ Genus: Alphacoronavirus } & $\begin{array}{l}\text { Alphacoronavirus } 1 \mathrm{a} \\
\text { Canine coronavirus }(\mathrm{CCoV}) \\
\text { Feline coronavirus }(\mathrm{FCoV})\end{array}$ \\
\hline & $\begin{array}{l}\text { Alphacoronavirus 1b } \\
\text { Human coronavirus 229E (HCoV-229E) } \\
\text { Human coronavirus NL63 (HCoV-NL63) }\end{array}$ \\
\hline \multirow[t]{3}{*}{ Genus: Betacoronavirus } & $\begin{array}{l}\text { Betacoronavirus A } \\
\text { Human coronavirus OC43 (HCoV-OC43) } \\
\text { Human coronavirus HKU1 (HCoV-HKU1) } \\
\text { Bovine coronavirus (BCoV) } \\
\text { Murine hepatitis coronavirus (MHV) } \\
\text { Canine respiratory coronavirus } \\
\text { Dromedary camel coronavirus HKU23 } \\
\text { Equine coronavirus } \\
\text { Porcine hemagglutinating encephalomyelitis virus }\end{array}$ \\
\hline & $\begin{array}{l}\text { Betacoronavirus B } \\
\text { Severe acute respiratory syndrome (SARS)-related coronavirus }\end{array}$ \\
\hline & $\begin{array}{l}\text { Betacoronavirus } \mathrm{C} \\
\text { Pipistrellus bat coronavirus HKU5 } \\
\text { Tylonycteris bat coronavirus HKU4 } \\
\text { Middle East Respiratory Syndrome (MERS-CoV) } \\
\text { Betacoronavirus D } \\
\text { Rousettus bat coronavirus HKU9 (BtCoV-HKU9) }\end{array}$ \\
\hline Genus: Deltacoronavirus & $\begin{array}{l}\text { Munia coronavirus HKU13 } \\
\text { Porcine coronavirus HKU15 } \\
\text { Sparrow coronavirus HKU17 }\end{array}$ \\
\hline $\begin{array}{l}\text { Genus: } \\
\text { Gammacoronavirus }\end{array}$ & $\begin{array}{l}\text { Infectious bronchitis virus (IBV) } \\
\text { Turkey coronavirus (TCoV) } \\
\text { Duck coronavirus } \\
\text { Goose coronavirus } \\
\text { Pigeon coronavirus } \\
\text { Pheasant coronavirus } \\
\text { Beluga whale coronavirus SW1 }\end{array}$ \\
\hline
\end{tabular}

found in birds, except for the coronaviruses detected in beluga whale and bottlenose dolphin (Mihindukulasuriya et al. 2008; Woo et al. 2010).

\subsection{Morphology and Structure}

The virus possesses a round structure that is often 100 to $160 \mathrm{~nm}$ in diameter and with long, petal-shaped spikes on the virus surface (Gonzalez et al. 2003). Inside the virion is a single-stranded, positive-sense linear RNA genome. The helical nucleocapsid, unusual for positive-stranded RNA animal viruses, is enclosed by a lipoprotein envelope that contains long petal-shaped spike glycoprotein $(\mathrm{S})$; an integral membrane glycoprotein $(\mathrm{M})$ which spans the lipid bilayer three times; and an 


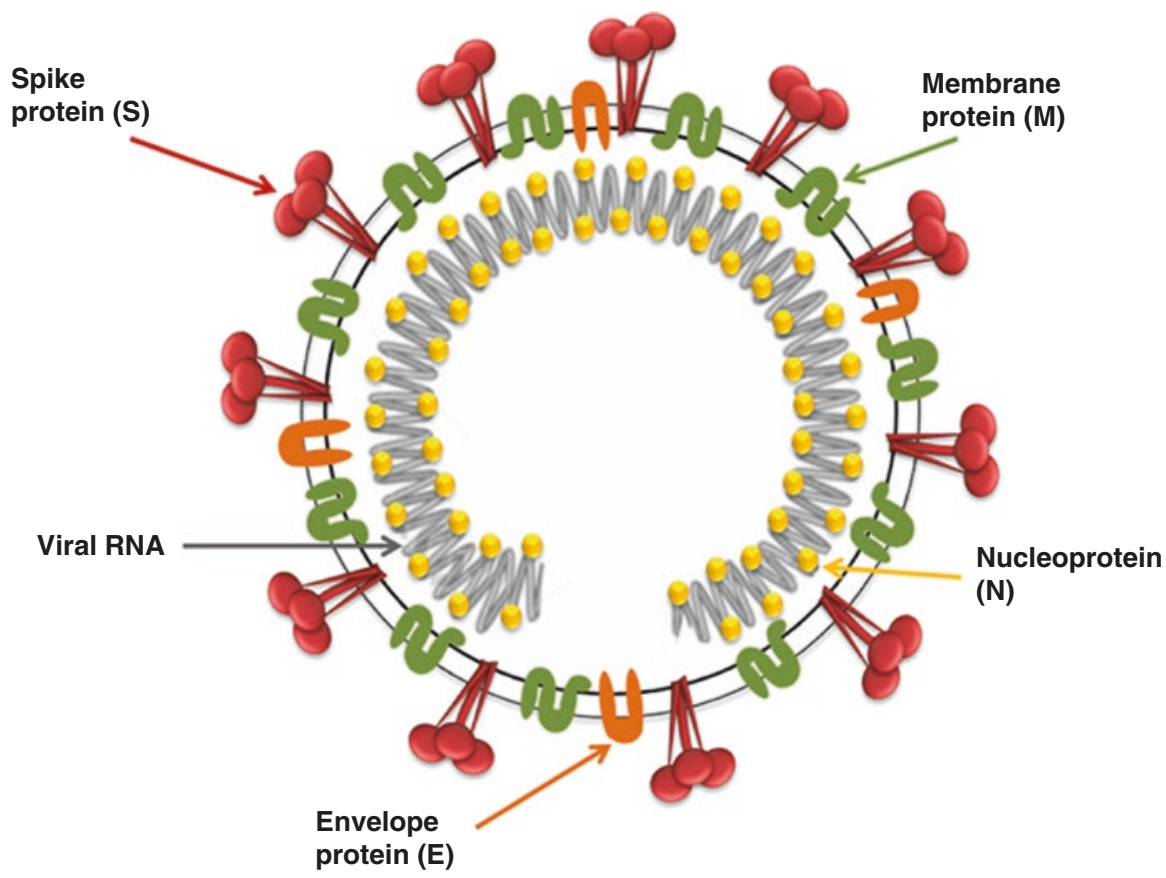

Fig. 5.1 Schematic diagram of the infectious bronchitis virus

envelope or small membrane (E) protein which is present in much smaller amounts than the other viral envelope proteins (Fig. 5.1).

\subsection{Genome}

IBV genome is a single-stranded, positive-sense linear genome with a cap at the $5^{\prime}$ end and poly(A) tail at the $3^{\prime}$ end (Boursnell et al. 1987). The viral genome is 27,62027,661 nucleotides (nts) in length excluding the polyadenylated tail. At the $5^{\prime}$ end of the genome, there is a leader sequence $(64 \mathrm{nt})$, which is followed by $5^{\prime}$ untranslated region (5'-UTR) of 528 nts (Ammayappan et al. 2008; Zhang et al. 2010; Abro et al. 2012). At the $3^{\prime}$ end of the RNA genome, there is 507-528 nts UTR, followed by a poly(A) sequence of variable length. At least ten open reading frames (ORFs) were detected (Zhang et al. 2010; Ammayappan et al. 2008): ORF1ab nonstructural protein (nsp) (529-20,360), ORF2 spike S glycoprotein (20,311-23,820, 3489 nts and 1162 amino acids [aa]), ORF3abc [3a, (23,820-23,993, 174 nts, 57 aa), 3b (23,993-24,187, $195 \mathrm{nts}, 64 \mathrm{aa}), 3 \mathrm{c}$ small envelope protein (E) (24,168-24,491, $330 \mathrm{nts}, 109 \mathrm{aa})$, ORF4, membrane glycoprotein (M) (24,469-25,140, 678 nts; 225 aa), ORF5ab [5a 198 nts $(25,500-25,697), 5 b 294$ nts $(25,694-25,942)]$, and ORF6 nucleoprotein N $(25,885-$ 27,114, $1230 \mathrm{nt}, 409 \mathrm{aa}$ ). The genome organization of classical IBV is 5'UTR-ORF1aORF1b-S-3a-3b-E-M-5a-5b-N- UTR 3' (Fig. 5.2); however, different genetic organizations were recorded 5' UTR-Pol-S-X1-E-M-N-UTR-3' or 5' UTR -Pol-SX1-E-M-5b-N-UTR3' (Mardani et al. 2008). 


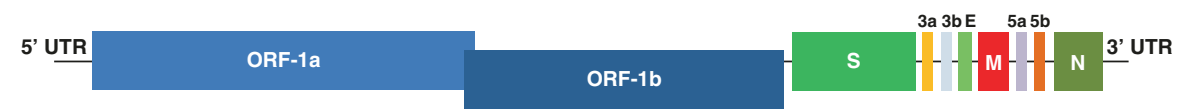

Fig. 5.2 Schematic diagram of IBV genome organization

\subsection{Structural Proteins}

\subsubsection{Spike Protein}

The spike protein is petal-shaped protrusions of about $20 \mathrm{~nm}$ in length that emerge from the virion envelope. A cleaved N-terminal signal peptide (Binns et al. 1985) directs the $\mathrm{S}$ protein toward the endoplasmic reticulum (ER) where it undergoes terminal N-linked glycosylation (Cavanagh 1983a, b). After glycosylation, the monomers oligomerize to form dimers or trimers (Cavanagh 1983a, b; Delmas and Laude 1990; Lewicki and Gallagher 2002). The S protein of IBV is cleaved by a furin-like host cell protease at the highly basic motif RRFRR generating S1 (90 $\mathrm{kDa})$ and S2 (84 kDa) subunits of about 500 and 600 amino acids in size, respectively (Cavanagh 1983a, b). The N-terminal part of S1 forms an ectodomain, while the C-terminal S2 subunit comprises a narrow stalk ectodomain, short transmembrane, and endodomain. All the receptor-binding domains (RBD) of IBV are located in S1 domain (Masters and Perlman 2013; Promkuntod et al. 2014). After endocytosis, conformational changes in the $\mathrm{S}$ protein are triggered by exposure to acidic $\mathrm{pH}$ in endosomes (Chu et al. 2006), resulting in fusion of the viral envelope with the cellular membrane. The nucleotide sequence of the S1 subunit is used for genotyping IBV isolates (OIE 2013). S protein contains epitopes for neutralization (Cavanagh 1983a, b; Kant et al. 1992; Koch et al. 1990; Mockett et al. 1984; Niesters et al. 1987b). In the S1 subunit, three hypervariable regions (HVRs) are located within amino acids 38-67, 91-141, and 274-387 (Kant et al. 1992; Koch et al. 1991). Neutralizing-serotype-specific epitopes are associated within the defined serotypes (Cavanagh et al. 1988; Niesters et al. 1987a; Jia et al. 1996). N38S, H43Q, P63S, and T69I amino acid substitutions lead to loss of the ability of M41 strain to bind to the trachea (Promkuntod et al. 2014).

\subsubsection{Matrix Protein}

Small domain of the M glycoprotein (25-33 kDa) is exposed to the exterior of the viral envelope. There is a triple membrane and a large carboxyl-terminal domain inside the viral envelope (Lai and Cavanagh 1997). M protein is glycosylated by $\mathrm{N}$ linkage (Lai and Cavanagh 1997). The M proteins are targeted to the pre-Golgi region. The $\mathrm{M}$ protein plays a key role in virus assembly and interacts with both $\mathrm{N}$ and S proteins (Kuo and Masters 2002; de Haan et al. 2002). The M protein may also be critical for packaging viral RNA into nucleocapsids, by specifically interacting with the viral RNA packaging signal (Narayanan et al. 2003). 


\subsubsection{Nucleocapsid Protein}

The $\mathrm{N}$ protein is a phosphoprotein of 50 to $60 \mathrm{kDa}$ that binds to the genomic RNA to form a helical ribonucleoprotein complex (Jayaram et al. 2005). The $\mathrm{N}$ protein interacts with $\mathrm{M}$, leading to the incorporation of nucleocapsid into virus particles (Kuo and Masters 2002). It plays a role in the induction of cytotoxic T lymphocytes (Seo et al. 1997; Collisson et al. 2000). In addition, novel linear B-cell epitope peptides were found in $\mathrm{N}$-terminal domain of $\mathrm{N}$ protein (Yu et al. 2010).

\subsubsection{Envelope Protein}

It is 9 to $12 \mathrm{kDa}$ protein associated with the viral envelope (Godet et al. 1992). The E protein transverses the lipid bilayer twice, with both termini of the protein present in the virus lumen (Maeda et al. 2001). Both the $\mathrm{M}$ and $\mathrm{E}$ proteins are required for budding from infected cells (Vennema et al. 1996). The expression of E alone is sufficient for vesicle release from transfected cells (Maeda et al. 1999). This protein is associated with viral envelope formation, assembly, budding, ion channel activity, and apoptosis (Corse and Machamer 2003; Wilson et al. 2006).

\subsection{IBV Genotypes}

It is suggested that the emergence of IBV appears to be a regular influx, and up to date, more than 65 different types do exist worldwide (Table 5.2). Different serotypes generally have large differences (20-50\%) in the deduced amino acid sequences of the S1 subunit (Kusters et al. 1989). IBV serotypes that share more than $95 \%$ amino acid identity in S1 should have cross protection, whereas IBV strains of other serotypes share less than $85 \%$ amino acid identity did not cross protect each other (Cavanagh and Gelb 2008). Poor cross protection was found in viruses that are clearly distinguishable in only $2-3 \%$ differences in amino acid sequences (Cavanagh 1991; Abdel-Moneim et al. 2006). This diversity in S1 probably results from mutation, recombination, and strong positive selection in vivo (Cavanagh et al. 1988, 1990). The widespread use of live attenuated vaccine strains and the subsequent selective pressure induced by neutralizing antibodies against the spike may force the adaptation of the virus to escape immunity and hence result in faster evolutionary rates (Jackwood 2012). Error prone during replication is not expected to constitute a major role in the evolution of IBV, since RdRp possesses exoribonuclease (ExoN) activity that provides some proofreading errors during coronavirus replication (Minskaia et al. 2006). During the replication of the IBV, both full genomic minus-strand template and the subgenomic minus-strand templates are generated by continuous and discontinuous unique mechanisms, respectively; the latter allows recombination between RNA viruses (Sawicki and Sawicki 1995). Although recombination was found throughout the whole IBV genome, hot spots of recombination have been found in the upstream of $S$ glycoprotein gene in 
Table 5.2 IBV genotypes in different countries

\begin{tabular}{|c|c|}
\hline Mass & Worldwide \\
\hline \multicolumn{2}{|c|}{ IBV types distributed worldwide or in multiple countries } \\
\hline $\begin{array}{l}\text { 793B(CR88/ 4-91vaccine) } \\
\text { (Cavanagh et al. 2005) }\end{array}$ & $\begin{array}{l}\text { UK (Gough et al. 1992)/Brazil (De Wit et al. 2015)/France } \\
\text { (Cavanagh et al. 2005)/India (Sumi et al. 2012)/Egypt (Sultan } \\
\text { et al. 2004)/Israel (Gelb Jr et al. 2005)/India (Elankumaran } \\
\text { et al. 1999)/Spain (Worthington et al. 2008)/Ukrania } \\
\text { (Ovchinnikova et al. 2011)/Nigeria (Ducatez et al. 2009)/ } \\
\text { Mexico (Jackwood et al. 2005; Cook et al. 1996)/Thailand } \\
\text { (Promkuntod et al. 2015)/China (Han et al. 2011)/Japan } \\
\text { (Ariyoshi et al. 2010)/Thailand (Cook et al. 1996)/Canada } \\
\text { (Martin et al. 2014)/Russia (Bochkov et al. 2006)/Morocco } \\
\text { (Fellahi et al. 2015) }\end{array}$ \\
\hline China-type I (LX4-type)/QX & $\begin{array}{l}\text { China (Han et al. 2011)/Russia (Bochkov et al. 2006)/Europe } \\
\text { (Worthington et al. 2008)/Korea(K-II) (Lim et al. 2012)/Japan } \\
\text { (Ariyoshi et al. 2010)/South Africa (Sigrist et al. 2012) } \\
\text { (Knoetze et al. 2014)/Thailand (Promkuntod et al. 2015) }\end{array}$ \\
\hline China-type IV(LDL/Q1) & $\begin{array}{l}\text { China (Han et al. 2011)/Taiwan (Chen et al. 2009)/Colombia } \\
\text { (Jackwood 2012)/Chile (Jackwood 2012)/Italy (Toffan et al. } \\
\text { 2013a)/Canada (Martin et al. 2014)/Saudi Arabia (Ababneh } \\
\text { et al. 2012), Jordan (Ababneh et al. 2012), Iraq (Ababneh } \\
\text { et al. 2012) }\end{array}$ \\
\hline D207 (D274) & $\begin{array}{l}\text { Europe (Davelaar et al. 1984; Worthington et al. 2008)/ } \\
\text { Nigeria (Ducatez et al. 2009)/Egypt (Madbouly et al. 2002)/ } \\
\text { Russia (Bochkov et al. 2006) }\end{array}$ \\
\hline Arkansas [Gray/JMK] & $\begin{array}{l}\text { Kazakhstan (Ovchinnikova et al. 2011)/Mexico (Quiroz et al. } \\
\text { 1993)/Japan (Ariyoshi et al. 2010)/Brazil (De Wit et al. 2015) }\end{array}$ \\
\hline USA/Connecticut & $\begin{array}{l}\text { USA/Canada (Martin et al. 2014)/Mexico (Jackwood et al. } \\
\text { 2005)/Argentina (Rimondi et al. 2009)/Colombia (Alvarado } \\
\text { et al. 2005) }\end{array}$ \\
\hline Italy-02 & $\begin{array}{l}\text { Europe (Jones et al. 2005)/Morocco (Fellahi et al. 2015)/ } \\
\text { Ukraine148]/Slovania (Ovchinnikova et al. 2011) Russia } \\
\text { (Bochkov et al. 2006) }\end{array}$ \\
\hline Eg-Var-I/IS-Var II & $\begin{array}{l}\text { Egypt (Abdel-Moneim et al. 2002;Abdel-Moneim et al. } \\
\text { 2012)/Israel (Gelb Jr et al. 2005)/Turkey[HM802259.1]/Iraq } \\
\text { (Mahmood et al. 2011)/Libya (Awad et al. 2014)/Oman } \\
\text { (Al-Shekaili et al. 2015) }\end{array}$ \\
\hline Eg-Var-II & $\begin{array}{l}\text { Egypt (Abdel-Moneim et al. 2012)/Libya (Awad et al. 2014)/ } \\
\text { Oman (Al-Shekaili et al. 2015) }\end{array}$ \\
\hline B1648 & $\begin{array}{l}\text { Russia (Bochkov et al. 2006)/Belgium (Reddy et al. 2015)/ } \\
\text { Nigeria (Ducatez et al. 2009)/Cuba (Acevedo et al. 2013) }\end{array}$ \\
\hline $\begin{array}{l}\text { Australia/Group I (Vic.S, } \\
\text { N1/62, N3/62, N9/74) }\end{array}$ & $\begin{array}{l}\text { Australia (Ignjatovic et al. 2006) New Zealand (McFarlane } \\
\text { and Verma 2008)/China (Han et al. 2011;Jackwood 2012) }\end{array}$ \\
\hline \multicolumn{2}{|c|}{ IBV types restricted to certain region or country } \\
\hline $\begin{array}{l}\text { USA/California/CA } 99 \text { USA } \\
\text { (Mondal and Cardona 2007)/ } \\
\text { Canada (Martin et al. 2014) }\end{array}$ & $\begin{array}{l}\text { Netherlands/D3128(Davelaar et al. 1984) Egypt (El-Kady } \\
\text { 1989) }\end{array}$ \\
\hline $\begin{array}{l}\text { USA/California / } \\
\text { CA/557/03(Jackwood et al. } \\
\text { 2007) }\end{array}$ & Italy/624/I (Capua et al. 1994) \\
\hline
\end{tabular}


Table 5.2 (continued)

\begin{tabular}{|c|c|}
\hline Mass & Worldwide \\
\hline $\begin{array}{l}\text { USA/California CA/1737/04 } \\
\text { USA (Jackwood et al. 2007)/ } \\
\text { Canada (Martin et al. 2014)/ } \\
\text { Cuba (Acevedo et al. 2013) }\end{array}$ & Turkey/IBV/Turkey/BB012/VIR9657/2012 [C404845] \\
\hline $\begin{array}{l}\text { USA/Delaware 072 USA } \\
\text { (Gelb et al. 1997)/Canada } \\
\text { (Martin et al. 2014) }\end{array}$ & Russia/RF1(Bochkov et al. 2006) \\
\hline $\begin{array}{l}\text { USA/Georgia/GA98 (Lee } \\
\text { et al. 2001) }\end{array}$ & Russia/RF1(Bochkov et al. 2006) \\
\hline $\begin{array}{l}\text { USA/Georgia/GA11 } \\
\text { (Jackwood 2012) }\end{array}$ & Russia/RF2 (Bochkov et al. 2006) \\
\hline $\begin{array}{l}\text { USA/Georgia/GA08 } \\
\text { (Jackwood et al. 2010b) }\end{array}$ & Russia/RF3(Bochkov et al. 2006) \\
\hline $\begin{array}{l}\text { USA/Georgia/GA07 } \\
\text { (Jackwood 2012) }\end{array}$ & Russia/RF4(Bochkov et al. 2006) \\
\hline $\begin{array}{l}\text { USA/PA/Wolgemuth/98 USA } \\
\text { (Ziegler et al. 2002)/Canada } \\
\text { (Martin et al. 2014) }\end{array}$ & Russia/RF5(Bochkov et al. 2006) \\
\hline $\begin{array}{l}\text { USA/PA/1220/98 USA } \\
\text { (Ziegler et al. 2002)/Canada } \\
\text { (Martin et al. 2014) }\end{array}$ & Russia/RF6(Bochkov et al. 2006) \\
\hline $\begin{array}{l}\text { Canada/Qu_mv (Martin et al. } \\
\text { 2014) }\end{array}$ & China-type II (CK/CH/LSC/99I-type) (Han et al. 2011) \\
\hline $\begin{array}{l}\text { Mexico/47/UNAM/01 } \\
(\text { Jackwood 2012) }\end{array}$ & $\begin{array}{l}\text { China-type III (KM-91-like)(Korea/K-II) (Han et al. 2011) } \\
\text { (Lim et al. 2012) }\end{array}$ \\
\hline $\begin{array}{l}\text { Mexico/7277/99 (Gelb et al. } \\
\text { 2001) }\end{array}$ & China/BJ (Han et al. 2011) \\
\hline $\begin{array}{l}\text { Mexico/07,484/98 (Callison } \\
\text { et al. 2001) }\end{array}$ & China/CK/CH/LHLJ/95I-type (Han et al. 2011) \\
\hline $\begin{array}{l}\text { Mexico/UNAM-97/97 } \\
\text { (Escorcia et al. 2000) }\end{array}$ & Japan/JP-I (Ariyoshi et al. 2010) \\
\hline $\begin{array}{l}\text { Mexico/2001/47/UNAM } \\
{[\text { EU526405.1] }}\end{array}$ & Japan/JP-II (Ariyoshi et al. 2010) \\
\hline $\begin{array}{l}\text { Argentina/Clus A (Rimondi } \\
\text { et al. 2009) }\end{array}$ & Korea/K-I (Lim et al. 2012) \\
\hline $\begin{array}{l}\text { Argentina/Clus B (Rimondi } \\
\text { et al. 2009) }\end{array}$ & Korea/New cluster 1 (Lim et al. 2012) \\
\hline $\begin{array}{l}\text { Argentina/Clus C (Rimondi } \\
\text { et al. 2009) }\end{array}$ & Korea/New cluster 2 (Lim et al. 2012) \\
\hline Brazil/01 (De Wit et al. 2015) & Taiwan/Group I (Ma et al. 2012) \\
\hline Brazil/02(De Wit et al. 2015) & Taiwan /Group II (Taiwan/China)(Ma et al. 2012) \\
\hline Brazil/03(De Wit et al. 2015) & Thailand/THA001(Promkuntod et al. 2015) \\
\hline Brazil/04(De Wit et al. 2015) & Malaysia/MH5365/95 (Zulperi et al. 2009) \\
\hline
\end{tabular}


Table 5.2 (continued)

\begin{tabular}{l|l}
\hline Mass & Worldwide \\
\hline $\begin{array}{l}\text { Australia Group II (N1/88, } \\
\text { Q3/88 / V18/91) (Ignjatovic } \\
\text { et al. 2006) }\end{array}$ & India/PDRC/Pune/Ind/1/00 (Bayry et al. 2005) \\
\hline $\begin{array}{l}\text { Australia/subgroup 3/ (N1/03, } \\
\text { N4/02, N5/03, N4/03) } \\
\text { (Ignjatovic et al. 2006) }\end{array}$ & Tunisia/TN20/00 (Bourogaa et al. 2009) \\
\hline $\begin{array}{l}\text { Netherlands/D212 (D1466 } \\
\text { vaccine) (Davelaar et al. 1984) }\end{array}$ & Morocco/Moroccan type (Fellahi et al. 2015) \\
\hline
\end{tabular}

the nonstructural proteins 2, 3, and 16, in the $\mathrm{E}$ and $\mathrm{M}$ genes as well as the area near the 3' UTR (Thor et al. 2011). Recombination in different genes of IBV could affect the pathogenicity and virus virulence, but recombination of the $\mathrm{S}$ gene may result in the emergence of new strains, new serotypes, or even new viruses infecting other hosts (Jackwood et al. 2010a). Natural intergenic and intertypic recombination occurs naturally in an extensive manner (Cavanagh et al. 1992b; Wang et al. 1993; Jia et al. 1995; Lee and Jackwood 2000; Brooks et al. 2004; Bochkov et al. 2007; Ammayappan et al. 2008; Kuo et al. 2010; Mardani et al. 2010; Pohuang et al. 2011; Ovchinnikova et al. 2011; Thor et al. 2011; Liu et al. 2013; Song et al. 2013; Zhao et al. 2013; Hewson et al. 2014; Zhang et al. 2015). Interestingly, mosaic S1-containing recombinants from three different genotypes (H120, QX, D274) were reported in Russia (Ovchinnikova et al. 2011). In addition, recombination of distant unrecognized gammacoronavirus with a known IBV strain resulted in the evolution of gammacoronavirus able to infect turkeys (Jackwood et al. 2010a).

\subsection{Replication}

\subsubsection{Attachment}

The first step in the viral replication cycle is the binding of virions to the plasma membranes of the target cells. The cell receptor for IBV has yet to be elucidated. Only $\alpha$-2, 3-linked sialic acid has shown to be essential for spike attachment (Wickramasinghe et al. 2011; Winter et al. 2008; Abd El Rahman et al. 2009; Promkuntod et al. 2014). After the virus binds to a specific receptor, it enters the cell, a step that involves fusion of the viral envelope with plasma membrane.

\subsubsection{Penetration and Uncoating}

The binding of virus with the receptor induces a conformational change of the $S$ protein that activates the membrane fusion activity. After virus-membrane fusion, the viral nucleocapsid is released into the cytoplasm, and the RNA is uncoated to become available for translation and transcription. 


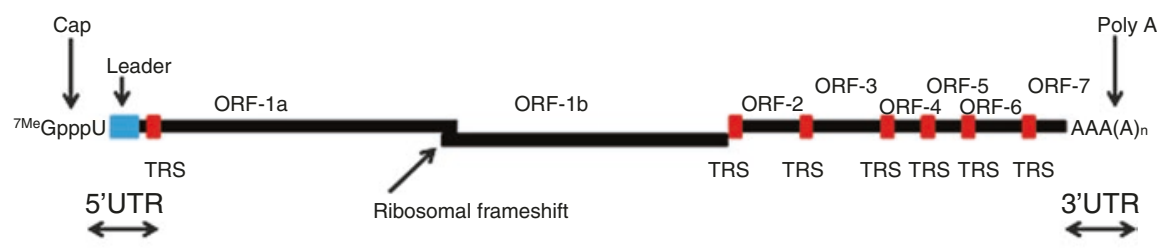

Leader TRS

Genomic RNA

TRS TRS TRSTRSTRS TRS

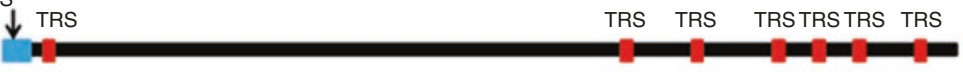

Subgenomic mRNA transcript

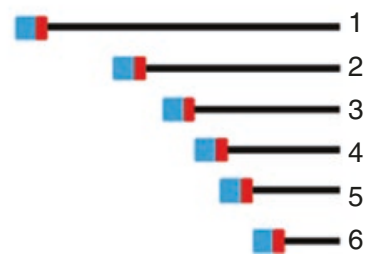

Fig. 5.3 Schematic diagram of the IBV genomic RNA and subgenomic mRNA transcripts. The nested set of seven IBV mRNAs (genome and sg mRNAs 2-6) is depicted below. The blue box is leader TRS, while red boxes indicate the position of the body TRSs

\subsubsection{Transcription and Translation of Viral RNA}

After the release of the viral RNA into the cytoplasm, the ORFs $1 \mathrm{a}$ and $1 \mathrm{~b}$ are translated into functional nonstructural proteins, which comprise the RNA replicasetranscriptase complex. This replicase-transcriptase complex synthesizes a full-length negative-sense RNA copy, which is used as a template for the transcription of fulllength and six subgenomic mRNAs that possess identical $3^{\prime}$ ends but different lengths (Fig. 5.3) (Sawicki and Sawicki 1990; Sethna et al. 1989). The initiation point of each mRNA corresponds to a stretch of consensus sequences, called intergenic sequences or transcription-regulatory sequences (TRSs, 5' CT(T/G) $\left.\mathrm{AACAA}(\mathrm{A} / \mathrm{T}) 3^{\prime}\right)$ that are found at the $3^{\prime}$ end of the leader sequence and at different positions upstream of genes in the genomic $3^{\prime}$-proximal domain of IBV. The $5^{\prime}$ twothirds of the genome, $1 \mathrm{a}$ and $1 \mathrm{~b}$, encoding polyprotein precursor that is translated into a large polyprotein, 1ab, through a ribosomal frameshift mechanism (Brierley et al. 1989) and processed into 15 nonstructural proteins (nsp2-16) involved in virus replication. Papain-like proteinase $\left(\mathrm{PL}^{\mathrm{pro}}\right)$, main protease $\left(\mathrm{M}^{\mathrm{pro}}\right)$ or $3 \mathrm{CL}^{\text {pro }}$ (because it has some similarities to the $3 \mathrm{C}$ proteases of picornaviruses), adenosine diphosphate-ribose 1-phosphatase (nsp3), RNA-dependent RNA polymerase (nsp12, RdRp), and RNA helicase (nsp13), exonuclease (nsp14), endoribonuclease (nsp15), and 2-O-methyltransferase (nsp16) (Snijder et al. 2003; Fang et al. 2010) are among the important replication enzymes encoded by the replicase gene. Exonuclease and endoribonuclease are involved in processing RNA (Ivanov et al. 2004; Fang et al. 2010). The remaining $3^{\prime}$ third of the genome encoding the 
structural genes in addition to accessory genes interspersed within the structural gene region. Each viral subgenomic mRNA is used for translation of a single viral protein. The four structural proteins, spike $(\mathrm{S})$, nucleocapsid $(\mathrm{N})$, membrane $(\mathrm{M})$, and envelope (E) proteins, are translated from separate mRNA. The accessory genes encode gene products although not essential for virus replication, but their deletion often causes viral attenuation (de Haan et al. 2002).

\subsubsection{Replication of Viral Genomic RNA}

IBV genome replication occurs through continuous transcription, while the subgenomic RNA synthesis occurs through discontinuous transcription (Fig. 5.3) (Masters 2006; Pasternak et al. 2006; Sawicki and Sawicki 2005; Tan et al. 2012). In addition to the replicase gene, the $5^{\prime}$ and $3^{\prime}$ end UTR sequences, with some specific secondary structures, are required for genomic RNA replication. The nucleocapsid $(\mathrm{N})$ is also required for efficient viral RNA synthesis (Verheije et al. 2010; Zuniga et al. 2010). The genome-size transcripts are packaged into progeny virions.

\subsubsection{Assembly and Release}

IBV assembles and buds intracellularly into the lumen of a smooth-walled, tubulovesicular compartment located intermediately between the rough endoplasmic reticulum and Golgi (Klumperman et al. 1994). After budding, virus particles are transported through a functional Golgi stack and are released out of the host cells by the exocytic pathway. A strong interaction between IBV $\mathrm{E}$ and $\mathrm{M}$ occurs where $\mathrm{E}$ protein provides a temporary anchor to relocate $\mathrm{M}$ in the pre-Golgi compartments, as it "prepares" the membranes for budding (Raamsman et al. 2000). The spike (S) protein contains a canonical dilysine endoplasmic reticulum retrieval signal ($\mathrm{KKXX}-\mathrm{COOH})$ in its cytoplasmic tail that plays an important role in protein accumulation near the budding sites (Ujike and Taguchi 2015). The virus nucleocapsid is enclosed by a lipoprotein envelope during virus budding from intracellular membranes. The envelope contains $\mathrm{S}, \mathrm{M}$, and $\mathrm{E}$ proteins.

\subsection{Epizootiology}

\subsubsection{Hosts}

All ages of chicken are susceptible to infection with IBV. The virus induces more severe disease in baby chicks, and the severity decreases as the age increases. IBV infection was also recorded in peafowl and also in non-galliform birds, e.g., the teal (Liu et al. 2005). 


\subsubsection{Transmission}

IBV is a highly contagious airborne infection (Cumming 1970; OIE 2013) that can be easily transmitted directly by chicken to chicken through aerosols and indirectly contact via contamination of personnel or equipment, egg packing materials, litter, and farm visits (OIE 2013; Cavanagh and Gelb 2008). IBV can establish persistent infections when it affects the genital system of birds during early days of life; virus shedding is detected approximately when the egg production started. Reports of extended and intermittent shedding through nasal and fecal discharge are evident and could constitute a potential risk of flock-to-flock transmission (Jones and Ambali 1987; Adzhar et al. 1996; Alexander and Gough 1978; Cook 1968; Alexander and Gough 1977).

\subsubsection{Incubation Period}

The incubation period of IBV is very short $18-36 \mathrm{~h}$ and it depends on the infecting dose of the virus, and the clinical signs appear within 24-48 h of virus exposure (Hofstad and Yoder 1966).

\subsubsection{Clinical Signs}

The clinical picture includes decreased in the general bird vitality, huddling under a heat source, and decrease in both food and water consumption. The respiratory clinical form of IBV infection in chicks includes: nasal discharge, sneezing, coughing, and gasping. Some chicks may develop wet eyes and swollen sinuses. In chickens more than 6 weeks of age and older, the signs are similar to those in chicks, and the respiratory clinical form occurs but in a milder form (Cavanagh and Gelb 2008). Nephropathogenic viruses induce respiratory distress in addition to signs of ruffled feathers, wet droppings, increased water intake, and mortality (Winterfield and Hitchner 1962). In laying flocks, declines in egg production and quality are seen in addition to respiratory signs. About 6 to 8 weeks may elapse before production returns to the pre-infection level, but in some cases, this is never attained. The severity of the production declines may vary with the period of lay (van Eck 1983). In addition to production declines, the number of eggs unacceptable for setting is increased, hatchability is reduced, and soft-shelled, misshapen, and rough-shelled eggs are produced (Crinion 1972). The albumen may be thin and watery without definite demarcation between the thick and thin albumen of the normal fresh egg. Infectious bronchitis virus infection of 1-day-old chicks can produce permanent damage to oviducts leading to reduced egg production and inferior quality eggs when the chickens come into lay. The severity of oviduct lesions is likely to be less in infections of older chickens, and some serotypes may fail to produce any pathologic change even in infections of 1-day-old chicks. The presence of specific 
maternal antibody was also shown to protect the oviduct from damage due to IBV infection in early life (Chew et al. 1997).

\subsubsection{Gross Lesions}

Infected chicken showed petechial lesions in the larynx and tracheal exudate, which can be serous or caseous. Cloudy air sacs may be noticed in some birds. Caseous plug in the tracheal bifurcation could also be seen in some birds. Small areas of pneumonia may be observed in the lungs (Cavanagh and Gelb 2008). In nephropathogenic strains, the kidneys are swollen and the ureters are distended with urates (Ziegler et al. 2002; Abdel-Moneim et al. 2005). Some IBV strains are associated with thickening of the proventricular wall with congestion at the point of emergence of the glandular ducts (Toffan et al. 2013b). Cystic oviducts were observed in layer birds infected very early during the first days of life. Birds infected at the time of lay have reduced size and weight of the oviduct and regression of the ovaries. The fluid yok material may be observed in the abdominal cavity.

\subsubsection{Histopathology}

Loss of cilia of the tracheal mucosa and minor infiltration of heterophils and lymphocytes are detected 18-24 h after infection. Hyperplasia is followed by massive lymphocytic infiltration of the lamina propria may be present after 7 days. In nephrogenic strains, interstitial nephritis, infiltration of heterophils in the interstitium, and (Cavanagh and Gelb 2008; Abdel-Moneim et al. 2006) sometime renal hemorrhages are observed (Abdel-Moneim et al. 2005; Abdel-Moneim et al. 2006) (Fig. 5.4). The oviduct of mature hens showed decreased height and loss of cilia, infiltration by lymphocytes, and edema as well as fibroplasia of the mucosa of all regions of the oviduct (Sevoian and Levine 1957). Multifocal erosion and necrosis of the tunica mucosa and glandular epithelium of the proventriculus are associated with lymphocytic infiltration and fibroplasia in the lamina propria (Toffan et al. 2013b).

\subsection{Pathogenicity}

IBV initially infects ciliated and mucus-secreting cells of the upper respiratory tract (Raj and Jones 1997). Maximum virus shedding occurs 3-5 days after infection in the nose and trachea (Cavanagh 2003; Hofstad and Yoder 1966; Ambali and Jones 1990). High virus titers occur also in the lungs and air sacs (Raj and Jones 1997). 


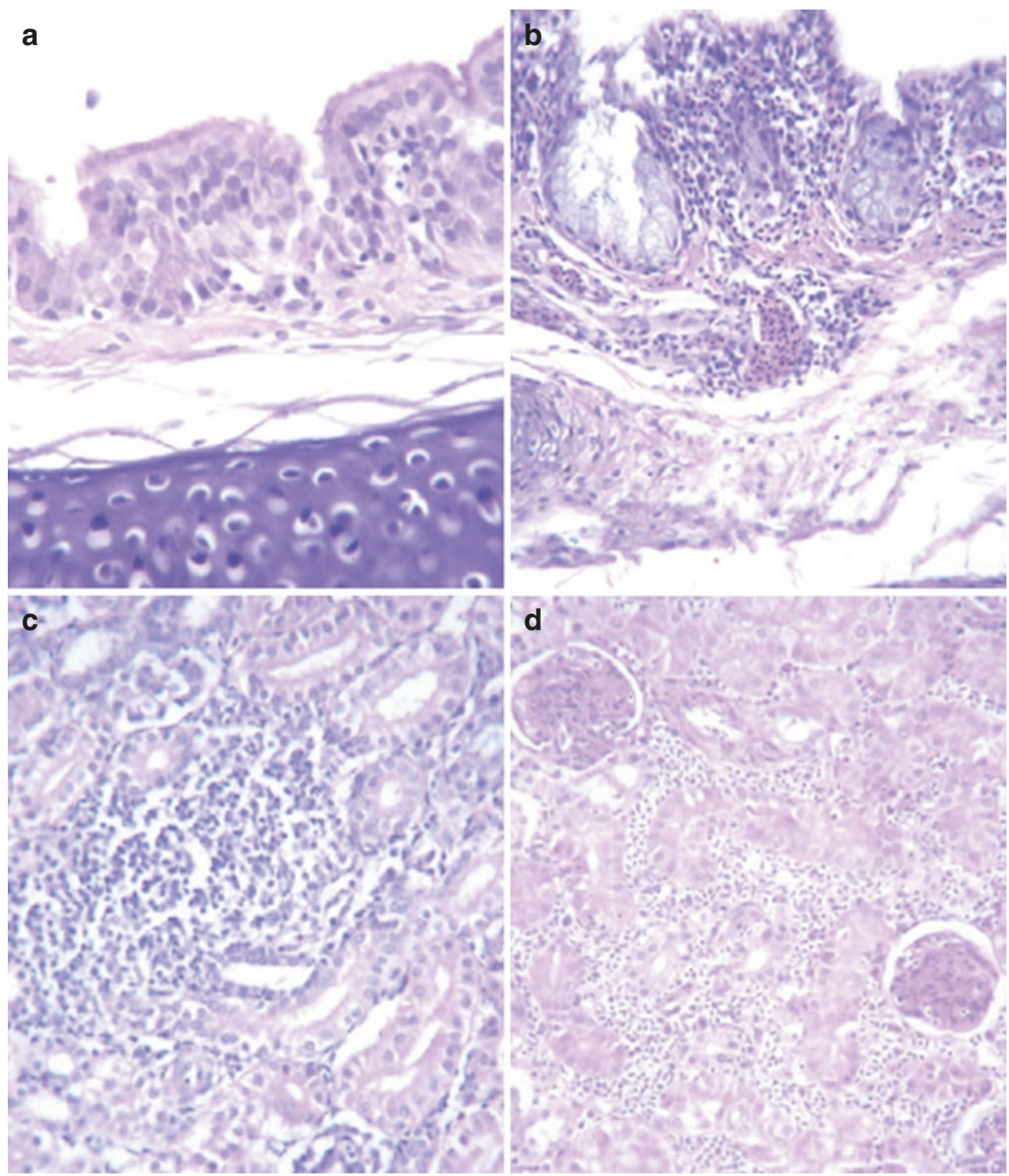

Fig. 5.4 Trachea and kidney histopathology following experimental infection of 1-day-old chicken with Egypt/F/03 (Abdel-Moneim et al. 2006). Trachea and kidney stained with H\&E. (a) Trachea of chickens 5 days postinfection with Egypt/F/03 showing hyperplasia, lymphocytic infiltration, and edema $(40 \times)$. (b) Trachea of chickens 7 days postinfection with Egypt/F/03 showing diffuse lymphocytic aggregation, degeneration of the epithelium mucus, and hemorrhages $(20 \times)$. (c) Kidney of chickens 5 days postinfection with Egypt/F/03 showing focal lymphocytic aggregation in the interstitium and glomeruli, as well as degenerative changes in tubular epithelium $(40 \times)$. (d) Kidney of chickens 7 days postinfection with Egypt/F/03 showing massive renal hemorrhages and degeneration of renal tubular epithelium $(20 \times)$ 


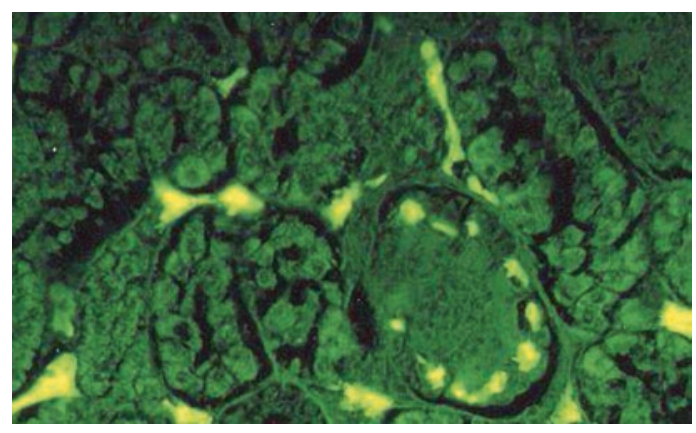

Fig. 5.5 Immunofluorescent staining of kidney paraffin section of kidney 5 days postinfection with Egypt/Beni-Suef/01 (Abdel-Moneim et al. 2005). Intracytoplasmic fluorescence in glomerular tuft and endothelial lining of renal blood vessels in the intertubular areas $(40 \times)$

IBV grows also in the epithelial lining of the kidney, oviduct, testes, esophagus, proventriculus, duodenum, jejunum, spleen, bursa of Fabricius, cecal tonsils, Harderian gland, rectum, and cloaca (Cavanagh 2003; Raj and Jones 1997; Abdel-Moneim et al. 2005; Ambali and Jones 1990; Seo et al. 1997) with minimal pathological effect. The virus commonly persists in the alimentary tract in young chickens (Ambali and Jones 1990; Alvarado et al. 2006) and in layers in the absence of clinical disease (Jones and Ambali 1987). Proventricular-type IBV (QX) reported in 1996 in China induces hemorrhagic ulceration of proventriculi and diarrhea followed by obvious signs of respiratory disease and high mortality (Zhou et al. 1998; GenCheng et al. 1998). Nephropathogenic strains result in considerable mortalities in meat-type birds (Cook et al. 2001; Lambrechts et al. 1993; Li and Yang 2001; Pensaert and Lambrechts 1994). The virus replicates in renal tubules and ducts, distal convoluted tubules, and Henle's loops (Chen and Itakura 1996) but may also replicate in the renal glomeruli (Fig. 5.5) (Abdel-Moneim et al. 2005). Modest to high titers of IBV in the kidney do not necessarily correlate with overt kidney disease, and there may be no gross kidney lesion (Ambali and Jones 1990). IBV infection of the chicken reproductive system leads to decreased egg production and quality due to the infection of the oviduct. In roosters, the virus results in epididymal stones, decreases sperm production, and decreases serum testosterone concentrations (Boltz et al. 2004). Infection is commonly followed by secondary bacterial infections, which may increase the mortality and complicate the clinical situation (Vandekerchove et al. 2004). Infection of enteric tissues usually does not manifest itself clinically.

\subsection{Immunity}

\subsubsection{Innate Immunity}

Hyperplasia of the goblet cells and alveolar mucous glands with subsequent increase in seromucous nasal discharge and catarrhal exudates in the trachea 
are the first response of the innate immunity against IBV infection (Nakamura et al. 1991). Toll-like receptor (TLR) 21 is stimulated by the presence of deoxyoligonucleotides containing $\mathrm{CpG}$ motifs, and it induces NF-кB production, leading to enhanced transcription of a number of cytokines (Brownlie et al. 2009). A rapid influx of macrophages to the infected tissue, detected within hours postinfection, plays an important role in limiting the replication of IBV within respiratory tissues. Heterophils are responsible for the destruction of IBV-infected cells during initial infection by phagocytosis and oxidative lysosomal enzyme release (Fulton et al. 1997). However, at the tracheal epithelium, heterophils do not reduce virus replication but worsen the severity of lesions (Raj et al. 1997). Interferon production in the plasma and all over body tissues (Otsuki et al. 1987), with simultaneous upregulation of mRNA levels of pro-inflammatory cytokines (IL-6 and IL-1 $\beta$ ) and lipopolysaccharideinduced tumor necrosis factor (TNF)- $\alpha$ factor, is produced during IBV infection. This coincides with the highest viral loads and microscopic lesions, indicating a potential role of these cytokines with high virus loads and the development of tracheal and kidney lesions (Okino et al. 2014; Jang et al. 2013; Chhabra et al. 2015). In contrast, il6 gene expression and upregulation of IFN$\gamma$, IL-8 (CXCLi2), and MIP-1 $\beta$ genes together with mannose-binding lectin (MBL), which activates complement, inhibit the propagation of the virus (JuulMadsen et al. 2007). Apoptosis is another nonspecific defense mechanism against IBV infection by premature lysis of infected cells, thereby aborting viral multiplication (Cong et al. 2013).

\subsubsection{Role of Antibodies in Protection}

Circulating antibody titers do not highly correlate with protection from IBV infection (Raggi and Lee 1965; Gough and Alexander 1979). In contrast, it has also been reported that high titers of humoral antibodies correlate well with the absence of virus re-isolation from the kidneys and genital tract (Gough et al. 1977; Macdonald et al. 1981; Yachida et al. 1985) and protection against a drop in egg production (Box et al. 1988). IBV-specific antibodies were suggested to be involved in limiting IBV spread by viremia from the trachea to other susceptible organs, including the kidneys and oviduct (Raj and Jones 1997). In general, serum antibody levels do not closely correlate with tissue protection, but local antibodies may contribute to the protection of the respiratory tract (Ignjatovic and McWaters 1991; Raggi and Lee 1965). Furthermore, IBV-specific IgA antibodies were first detected in tears and later in serum, which suggests that $\operatorname{IgA}$ is important in neutralizing IBV at mucosal surfaces and is thought to play a role in the control of IBV locally (Davelaar et al. 1982; Gelb et al. 1998). However, IgA might not be important in protection against IBV infection of the upper respiratory tract, whereas locally produced IgY, after a secondary immunization, provided effective protection against IBV by neutralizing this virus (Guo et al. 2008; Orr-Burks et al. 2014). 


\subsubsection{Cellular Immunity}

IBV-specific cytotoxic T cell lymphocyte (CTL) activity is dependent on the $\mathrm{S}$ and $\mathrm{N}$ proteins of IBV (Collisson et al. 2000), while of $\mathrm{CD}^{+} \mathrm{T}$ cells do not appear to be important in initially containing IBV infection in chickens (Seo et al. 2000); however, $\mathrm{CD}^{+}{ }^{+} \mathrm{T}$ cells and $\mathrm{B}$ cells could be more critical for long-term virus control (Chhabra et al. 2015). S1 and $\mathrm{N}$ but not the M protein proteins of IBV generated cytotoxic $\mathrm{T}$ cell responses. The whole $\mathrm{N}$ protein and its carboxy terminal region but not its amino terminal region were reported to induce a CTL response (Seo et al. 1997; Guo et al. 2010).

\subsubsection{Maternally Derived Antibodies}

Chicks hatched with high levels of maternally derived antibodies are protected against IBV challenge at 1 day of age but not at 7 days (>30 \%) (Mondal and Naqi 2001). Protection is correlated with levels of local antibody but not humoral antibody (Mondal and Naqi 2001).

\subsection{Diagnosis}

\subsubsection{Virus Isolation}

\subsubsection{Sampling}

Samples should be obtained as soon as possible after the appearance of the clinical signs. Laryngotracheal swabs from live birds or tracheal and lung tissues from fresh carcasses can be used for laboratory diagnosis of IBV. Kidney, oviduct, or proventriculus samples are collected from birds with nephritis, egg production, or proventriculitis, respectively. All samples should be placed in virus transport medium containing penicillin (10,000 International Units [IU]/ml) and streptomycin (10 mg/ $\mathrm{ml}$ ) and kept in ice and then frozen (OIE 2013).

\subsubsection{Virus Isolation in Embryonated Chicken Eggs}

Specific pathogen-free embryonated chicken egg (SPF-ECE) is recommended for primary isolation of IBV. Processed samples (10-20\% w/v) in phosphate-buffered saline (PBS) are used for egg inoculation, after being clarified by low-speed centrifugation and filtration through bacteriological filters. 100-200 $\mu 1$ of the processed sample is inoculated into the allantoic cavity of 9-11-day-old embryos (Delaplane 1947). Embryo mortalities within the first $24 \mathrm{~h}$ is considered nonspecific death. The allantoic fluids of inoculated eggs (36-48h post-inoculation) are harvested and pooled (Cunningham 1973; Cunningham and El Dardiry 1948). Blind passage into another set of eggs for up to a total of three to four passages is conducted. The last passage is left for 7 days to screen the presence of pathognomonic embryonic changes: stunted and curled embryos (Fig. 5.6) with feather dystrophy and urate 


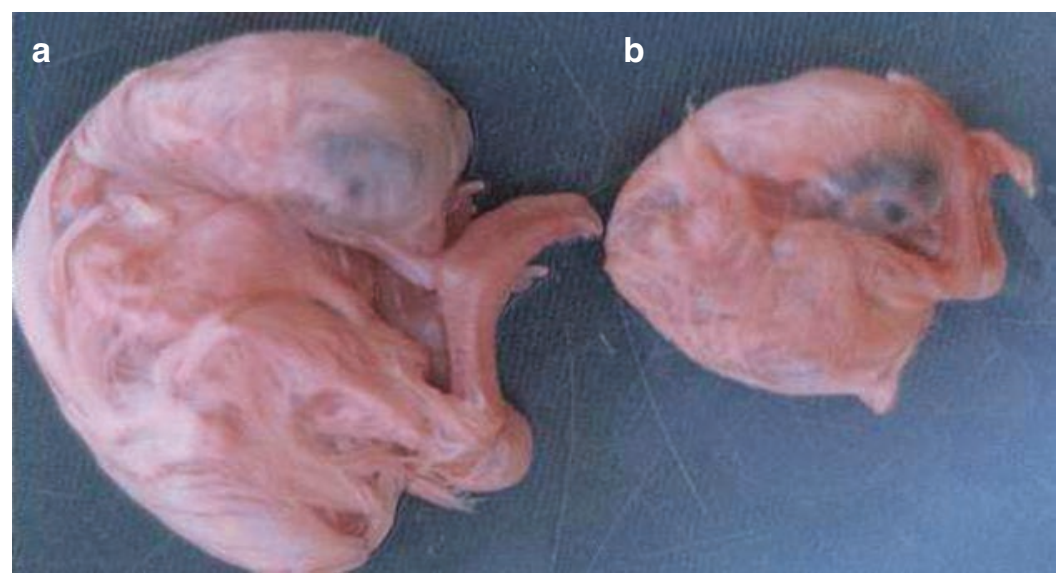

Fig. 5.6 Normal embryo (a) and stunted and dwarfed embryo following inoculation of specific pathogen-free embryonated chicken eggs with IBV (b)

deposits in the mesonephros. These lesions could also appear as early as the second passage (Delaplane 1947). The embryo-adapted strains induce more embryo mortalities. Isolation of IBV must be confirmed by serum neutralization or reverse transcription polymerase chain reaction (RT-PCR).

\subsubsection{Tracheal Ring Culture}

Tracheal ring culture (0.5-1.0 mm thick) from 19- to 20-day-old embryos can be used for primary isolation of IBV directly from field samples (Cook et al. 1976). The rings are maintained in Eagle's N-2-hydroxyethylpiperazine- $\mathrm{N}^{\prime}$-2- ethanesulfonic acid (HEPES) in roller drums (15 rev/hour) (OIE 2013). Ciliostasis within $24-48 \mathrm{~h}$ is an indication for virus multiplication; however, other viruses could produce similar lesions, so subsequent virus identification is needed.

\subsubsection{Biological and Immunological Identification}

IBV exerts hemagglutination (HA) activity only after phospholipase C treatment of concentrated virus infected allanto-aminiotic fluids (Bingham et al. 1975). A rapid plate HA test to detect neuraminidase-treated IBV in the allantoic fluid of ECE was introduced into the routine procedure of IBV identification and was found to correlate with the RT-PCR during the early stages of IBV detection and identification and isolation in ECE (Ruano et al. 2000). Such technique depends on the principle that IBV acquires its HA activity after removal of $\alpha 2$, 3-linked $\mathrm{N}$-acetyl neuraminic acid from the virion surface (Schultze et al. 1992). IBV can also be detected using immunofluorescence or immunoperoxidase on the tracheal or kidney section from the field isolates or on the chorioallantoic membrane or TOC from the inoculated embryos (Handberg et al. 1999; Abdel-Moneim et al. 2009; Bhattacharjee et al. 1994). However, nonspecific reactions or lower sensitivity especially in field 
samples may occur (Braune and Gentry 1965; Yagyu and Ohta 1990; Benyeda et al. 2010). The specificity of IFA may possibly be improved by using monoclonal antibodies (MAbs) (Naqi 1990; Yagyu and Ohta 1990; De Wit et al. 1995). Agar gel precipitation can be used for IBV identification, however, it possesses lower sensitivity in comparison to other assays (De Wit et al. 1992). Enzyme immunoassays are quick, inexpensive, and sensitive assays, which are suitable for screening large number of samples, IBV diagnosis, and serotype identification as well (Naqi 1990; Ignjatovic and McWaters 1991; Cavanagh et al. 1992a; Karaca and Syed 1993).

\subsubsection{Molecular Identification}

In situ hybridization can be used to detect viral nucleic acid (Collisson et al. 1990). RT-PCR and restriction fragment length polymorphism (RFLP) are used to genetically identify IBV (Kwon et al. 1993).

\subsubsection{Serotyping and Genotyping of IBV Strains}

Serotyping of IBV isolates has been conducted using hemagglutination inhibition (HI) (Alexander et al. 1983; King and Hopkins 1984) and virus neutralization (VN) tests in chick embryos (Dawson and Gough 1971), TOCs (Darbyshire et al. 1979), and cell cultures (Hopkins 1974). Enzyme-linked immunosorbent assays (ELISA) using MAbs are successfully used in serotyping IBV strains (Ignjatovic and McWaters 1991). The limitations of MAb analysis for IBV serotype definition are the lack of availability of MAbs or hybridomas and the need to produce new MAbs with appropriate specificity to keep pace with the evergrowing number of emerging IBV-variant serotypes (Karaca et al. 1992). There is a good correlation between the $\mathrm{S} 1$ sequence results and the VN serotyping (OIE 2013). The emergence of vast majority of the strains circulated worldwide (Jackwood 2012) renders serotyping impossible in many cases, and hence genotyping methods replaced $\mathrm{HI}$ and VN typing of IBV strains. Restriction fragment length polymorphism (RFLP) analysis of the $\mathrm{S} 1$ gene following RT-PCR amplification has been used to identify IBV serotypes (Lin et al. 1991; Kwon et al. 1993). Identification of IBV serotype is also conducted using serotype-specific $\mathrm{S} 1$ gene primer. Despite the success of both RFLP and serotype-specific RT-PCR, RFLP-derived restriction patterns of some IBV serotypes may be difficult to distinguish from others. Furthermore, samples containing mixture of more than one serotype may be difficult to be differentiated (Keeler et al. 1998). On the other hand, a mutation at a specific primer site or at an endonuclease recognition site may result in false negative in both RT-PCR and RFLP techniques. Direct sequencing of the $\mathrm{S} 1$ gene provides the ability to rapidly identify field strains including unrecognized variant virus serotypes (Kingham et al. 2000; Kusters et al. 1989). 


\subsubsection{Determination of IBV Protectotypes}

Antigenic and genetic variations among IBV alone are not adequate to define cross protection between strains (Cavanagh et al. 1997; Raggi and Lee 1965); hence, the term "protectotype" was suggested (Lohr 1988) to determine the cross protection afforded by the existing vaccines against the emerged serotypes/genotypes. Cross immunity tests (CIT) in experimental birds have been performed (Lambrechts et al. 1993; Darbyshire 1985, 1980); the use of tracheal organ cultures (TOCs) from IBVimmunized birds was also suggested (Darbyshire 1980) and used successfully (Hinze et al. 1991). Since IBV has a tropism for epithelial cells of the respiratory tract, kidney, oviduct, and gut of chickens, IBV vaccines are evaluated on the basis of protection afforded at the level of the trachea (McMartin 1993), the kidneys for nephropathogenic IBV (Lambrechts et al. 1993), and the oviduct level (Dhinakar Raj and Jones 1996).

\subsubsection{Serodiagnosis}

VN test may be performed in ECE, CKC, or tracheal organ culture (TOC). The test may be conducted using the constant serum-diluted virus or diluted virus content serum method (Gelb 1989). VN is highly specific and highly sensitive; it is rarely used because it is too expensive and time-consuming. HI test detects antibody earlier than NV and could be used for serology (Kaufhold et al. 1988; Gough and Alexander 1979, 1977). AGPT is proved to be specific but with poor sensitivity (De Wit et al. 1997). ELISA is used on a more frequent basis to measure IBV antibody (Garcia and Bankowski 1981; Marquardt et al. 1981; Soula and Moreau 1981; Snyder et al. 1985). Among the advantages of ELISA are the increased sensitivity and specificity (Garcia and Bankowski 1981; Marquardt et al. 1981; De Wit et al. 1997) and the automation of the ELISA steps and calculations (Snyder et al. 1983a, b).

\subsection{Treatment and Vaccination}

\subsubsection{Treatment}

No specific antiviral therapy is available to control IBV field infection. On the other hand, antimicrobial therapy may reduce the effect of the complicating bacterial infections. Increasing the ambient temperature may reduce mortalities in cold weather. Reduced mortalities in nephrogenic strains can be achieved by reducing the protein concentrations in ration, providing electrolytes in drinking water, and using diuretics. 


\subsubsection{Vaccination}

\subsubsection{Live Attenuated Vaccines}

Live attenuated IB vaccines are used to control IBV infection. Live vaccines are frequently attenuated by serial passage in embryonated chicken eggs (Klieve and Cumming 1988); however, extensive passage should be avoided to prevent the reduction in immunogenicity. There is an evidence that some attenuated vaccines showed increased in virulence after back passage in chickens (Hopkins and Yoder 1986). Vaccination is conducted by drinking water or coarse spray at 1 day or within the first week of age. Live vaccination of 1-day-old chicks induced a rapid decline in maternally derived antibodies due to binding and partial neutralization of vaccine viruses (Mondal and Naqi 2001). Booster vaccination is carried out 2-3 weeks after the first vaccination (Cavanagh 2003). The vaccine is administered individually by eyedrop, intratracheal, or intranasal route. Mass application by coarse spray, aerosol, and drinking water is used. In case of drinking water, removal of sanitizers and the incorporation of 1:4000 skim milk help to stabilize the vaccine titer during vaccination (Gentry and Braune 1972). Live attenuated IBV with NDV is used frequently; however, if excess IBV component is present, IBV may interfere with the NDV response (Thornton and Muskett 1975). Most of the commercially available live attenuated vaccines are derived from Massachusetts-based M41 serotype and the Dutch H52 and H120 strains, although some strains with regional impact have been introduced in different parts of the world in addition to Mass serotype (Lee et al. 2010; Bande et al. 2015). In the USA, strains belong to Connecticut, and Arkansas serotypes are used, whereas other serotypes like DE072 are used regionally. In some parts of Europe, D274, D1466, 4/91, and QX are used. In Australia, strains B and C subtypes are used (Klieve and Cumming 1988). In Egypt, MASS + CONN and 4/91 live attenuated vaccines and D274/M41 inactivated are used (Abdel-Moneim et al. 2006). In China, LDT3-A and QX live vaccines are used (Feng et al. 2015). Limitations of live attenuated vaccines include reversion to virulence, tissue damage, and interference by MDA. H52 and H120 IBV vaccines have been found to induce considerable pathology in the trachea (Bijlenga et al. 2004; Zhang et al. 2010). Potential recombination between vaccine strains and virulent field strains may lead to the emergence of new IBV serotypes (Lee et al. 2010; McKinley et al. 2008).

\subsubsection{Inactivated or Killed Vaccines}

Inactivated IBV vaccines are administered by injection to layers and breeders at point of lay (13-18 weeks of age). The inactivated vaccine may contain two IBV types and in association with other virus vaccines including NDV, egg drop syndrome, and others. Of course, inactivated vaccines require priming with live attenuated vaccines. In addition, inactivated autogenous vaccines prepared from specific local isolates can be used to immunize commercial layers and breeder chickens. 


\subsubsection{Recombinant Vaccines}

Recombinant IBV Beaudette with S proteins of virulent M41 (Hodgson et al. 2004; Hodgson et al., 2004) or 4/91 (S) (Armesto et al. 2011) or replacing the S1 ectodomain of the Beaudette with that of H120 (Wei et al. 2014) kept the viruses attenuated and provided homologous protection. Fowl pox virus vaccine expressing IBV-S1-gene and chicken interferon- $\gamma$ gene [rFPV-IFN $\gamma \mathrm{S} 1]$ and fowl adenovirus vectors (Shi et al. 2011; Johnson et al. 2003) as well as BacMam (baculovirus with mammalian expression system) expressing $\mathrm{S}$ and $\mathrm{N}$ genes (Abdel-Moneim et al. 2014) or S1 gene(Zhang et al. 2014) could be good candidates for IBV vaccines, since vectors replicate well in the bird's respiratory tract (Cavanagh 2007).

\section{References}

Ababneh M, Dalab AE, Alsaad S, Al-Zghoul M (2012) Presence of infectious bronchitis virus strain CK/CH/LDL/97I in the middle east. ISRN Vet Sci 2012:201721. doi:10.5402/2012/201721

Abd El Rahman S, El-Kenawy AA, Neumann U, Herrler G, Winter C (2009) Comparative analysis of the sialic acid binding activity and the tropism for the respiratory epithelium of four different strains of avian infectious bronchitis virus. Avian Pathol 38(1):41-45. doi:10.1080/03079450802632049

Abdel-Moneim A, Madbouly H, Gelb J, Ladman B (2002) Isolation and identification of Egypt/ Beni-Suef/01 a novel genotype of infectious bronchitis virus. Vet Med 50(4):1065-1078

Abdel-Moneim A, Madbouly H, El-Kady M (2005) In vitro characterization and pathogenesis of Egypt/Beni-Suef/01; a novel genotype of infectious bronchitis virus. Beni Suef Vet Med J 15(2):127-133

Abdel-Moneim AS, El-Kady MF, Ladman BS, Gelb J Jr (2006) S1 gene sequence analysis of a nephropathogenic strain of avian infectious bronchitis virus in Egypt. Virol $\mathrm{J}$ 3:78. doi:10.1186/1743-422x-3-78

Abdel-Moneim AS, Zlotowski P, Veits J, Keil GM, Teifke JP (2009) Immunohistochemistry for detection of avian infectious bronchitis virus strain M41 in the proventriculus and nervous system of experimentally infected chicken embryos. Virol J 6:15. doi:10.1186/1743-422x-6-15

Abdel-Moneim AS, Afifi MA, El-Kady MF (2012) Emergence of a novel genotype of avian infectious bronchitis virus in Egypt. Arch Virol 157(12):2453-2457. doi:10.1007/ s00705-012-1445-1

Abdel-Moneim AS, Giesow K, Keil GM (2014) High-level protein expression following single and dual gene cloning of infectious bronchitis virus $\mathrm{N}$ and $\mathrm{S}$ genes using baculovirus systems. Viral Immunol 27(2):75-81. doi:10.1089/vim.2013.0114

Abro SH, Renstrom LH, Ullman K, Belak S, Baule C (2012) Characterization and analysis of the full-length genome of a strain of the European QX-like genotype of infectious bronchitis virus. Arch Virol 157(6):1211-1215. doi:10.1007/s00705-012-1284-0

Acevedo AM, Martínez N, Brandão P, Perera CL, Frías MT, Barrera M, Pérez LJ (2013) Phylogenetic and molecular characterization of coronavirus affecting species of bovine and birds in Cuba. Biotecnol Apl 30:228-231

Adzhar A, Shaw K, Britton P, Cavanagh D (1996) Universal oligonucleotides for the detection of infectious bronchitis virus by the polymerase chain reaction. Avian Pathol 25(4):817-836. doi:10.1080/03079459608419184

Alexander DJ, Gough RE (1977) Isolation of avian infectious bronchitis virus from experimentally infected chickens. Res Vet Sci 23(3):344-347 
Alexander DJ, Gough RE (1978) A long-term study of the pathogenesis of infection of fowls with three strains of avian infectious bronchitis virus. Res Vet Sci 24(2):228-233

Alexander DJ, Allan WH, Biggs PM, Bracewell CD, Darbyshire JH, Dawson PS, Harris AH, Jordan FT, MacPherson I, McFerran JB, Randall CJ, Stuart JC, Swarbrick O, Wilding GP (1983) A standard technique for haemagglutination inhibition tests for antibodies to avian infectious bronchitis virus. Vet Rec 113(3):64

Al-Shekaili T, Baylis M, Ganapathy K (2015) Molecular detection of infectious bronchitis and avian metapneumoviruses in Oman backyard poultry. Res Vet Sci 99:46-52. doi:10.1016/j. rvsc.2014.12.018

Alvarado IR, Villegas P, Mossos N, Jackwood MW (2005) Molecular characterization of avian infectious bronchitis virus strains isolated in Colombia during 2003. Avian Dis 49(4):494-499. doi:10.1637/7202-050304r.1

Alvarado I, Villegas P, El-Attrache J, Jackwood M (2006) Detection of Massachusetts and Arkansas serotypes of infectious bronchitis virus in broilers. Avian Dis 50(2):292-297

Ambali A, Jones R (1990) Early pathogenesis in chicks of infection with an enterotropic strain of infectious bronchitis virus. Avian Dis 34:809-817

Ammayappan A, Upadhyay C, Gelb J Jr, Vakharia VN (2008) Complete genomic sequence analysis of infectious bronchitis virus Ark DPI strain and its evolution by recombination. Virol J 5:157. doi:10.1186/1743-422x-5-157

Ariyoshi R, Kawai T, Honda T, Tokiyoshi S (2010) Classification of IBV S1 genotypes by direct reverse transcriptase-polymerase chain reaction (RT-PCR) and relationship between serotypes and genotypes of strains isolated between 1998 and 2008 in Japan. J Vet Med Sci Jpn Soc Vet Sci 72(6):687-692

Armesto M, Evans S, Cavanagh D, Abu-Median AB, Keep S, Britton P (2011) A recombinant avian infectious bronchitis virus expressing a heterologous spike gene belonging to the $4 / 91$ serotype. PLoS One 6(8):e24352. doi:10.1371/journal.pone.0024352

Awad F, Baylis M, Ganapathy K (2014) Detection of variant infectious bronchitis viruses in broiler flocks in Libya. Int J Vet Sci Med 2(1):78-82

Bande F, Arshad SS, Bejo MH, Moeini H, Omar AR (2015) Progress and challenges toward the development of vaccines against avian infectious bronchitis. J Immunol Res 2015:424860. doi: $10.1155 / 2015 / 424860$

Bayry J, Goudar MS, Nighot PK, Kshirsagar SG, Ladman BS, Gelb J Jr, Ghalsasi GR, Kolte GN (2005) Emergence of a nephropathogenic avian infectious bronchitis virus with a novel genotype in India. J Clin Microbiol 43(2):916-918. doi:10.1128/jcm.43.2.916-918.2005

Beach J, Schalm O (1936) A filterable virus, distinct from that of laryngotracheitis, the cause of a respiratory disease of chicks. Poult Sci 15(3):199-206

Benyeda Z, Szeredi L, Mató T, Süveges T, Balka G, Abonyi-Tóth Z, Rusvai M, Palya V (2010) Comparative histopathology and immunohistochemistry of QX-like, Massachusetts and 793/B serotypes of infectious bronchitis virus infection in chickens. J Comp Pathol 143(4):276-283

Bhattacharjee P, Naylor C, Jones R (1994) A simple method for immunofluorescence staining of tracheal organ cultures for the rapid identification of infectious bronchitis virus. Avian Pathol 23(3):471-480

Bijlenga G, Cook JK, Gelb J Jr, de Wit JJ (2004) Development and use of the H strain of avian infectious bronchitis virus from the Netherlands as a vaccine: a review. Avian Pathol 33(6):550 557. doi:10.1080/03079450400013154

Bingham RW, Madge MH, Tyrrell DA (1975) Haemagglutination by avian infectious bronchitis virus-a coronavirus. J Gen Virol 28(3):381-390. doi:10.1099/0022-1317-28-3-381

Binns MM, Boursnell ME, Cavanagh D, Pappin DJ, Brown TD (1985) Cloning and sequencing of the gene encoding the spike protein of the coronavirus IBV. J Gen Virol 66(Pt 4):719-726. doi:10.1099/0022-1317-66-4-719

Bochkov YA, Batchenko GV, Shcherbakova LO, Borisov AV, Drygin VV (2006) Molecular epizootiology of avian infectious bronchitis in Russia. Avian Pathol 35(5):379-393. doi:10.1080/03079450600921008 
Bochkov YA, Tosi G, Massi P, Drygin VV (2007) Phylogenetic analysis of partial S1 and N gene sequences of infectious bronchitis virus isolates from Italy revealed genetic diversity and recombination. Virus Genes 35(1):65-71. doi:10.1007/s11262-006-0037-0

Boltz DA, Nakai M, Bahra JM (2004) Avian infectious bronchitis virus: a possible cause of reduced fertility in the rooster. Avian Dis 48(4):909-915. doi:10.1637/7192-040808r1

Bourogaa H, Miled K, Gribaa L, El Behi I, Ghram A (2009) Characterization of new variants of avian infectious bronchitis virus in Tunisia. Avian Dis 53(3):426-433. doi:10.1637/8666-022609-Reg.1

Boursnell ME, Brown TD, Foulds IJ, Green PF, Tomley FM, Binns MM (1987) Completion of the sequence of the genome of the coronavirus avian infectious bronchitis virus. J Gen Virol 68(Pt 1):57-77. doi:10.1099/0022-1317-68-1-57

Box PG, Holmes HC, Finney PM, Froymann R (1988) Infectious bronchitis in laying hens: the relationship between haemagglutination inhibition antibody levels and resistance to experimental challenge. Avian Pathol 17(2):349-361. doi:10.1080/03079458808436453

Braune MO, Gentry RF (1965) Standardization of the fluorescent antibody technique for the detection of avian respiratory viruses. Avian Dis 9(4):535-545

Brierley I, Digard P, Inglis SC (1989) Characterization of an efficient coronavirus ribosomal frameshifting signal: requirement for an RNA pseudoknot. Cell 57(4):537-547

Brooks JE, Rainer AC, Parr RL, Woolcock P, Hoerr F, Collisson EW (2004) Comparisons of envelope through 5B sequences of infectious bronchitis coronaviruses indicates recombination occurs in the envelope and membrane genes. Virus Res 100(2):191-198. doi:10.1016/j. virusres.2003.11.016

Brownlie R, Zhu J, Allan B, Mutwiri GK, Babiuk LA, Potter A, Griebel P (2009) Chicken TLR21 acts as a functional homologue to mammalian TLR9 in the recognition of CpG oligodeoxynucleotides. Mol Immunol 46(15):3163-3170. doi:10.1016/j.molimm.2009.06.002

Callison S, Jackwood M, Hilt D (2001) Molecular characterization of infectious bronchitis virus isolates foreign to the United States and comparison with United States isolates. Avian Dis 45:492-499

Capua I, Gough RE, Mancini M, Casaccia C, Weiss C (1994) A 'novel' infectious bronchitis strain infecting broiler chickens in Italy. Zentralbl Veterinarmed B 41(2):83-89

Cavanagh D (1983a) Coronavirus IBV glycopolypeptides: size of their polypeptide moieties and nature of their oligosaccharides. J Gen Virol 64(Pt 5):1187-1191. doi:10.1099/0022-1317-64-5-1187

Cavanagh D (1983b) Coronavirus IBV: structural characterization of the spike protein. J Gen Virol 64(Pt 12):2577-2583. doi:10.1099/0022-1317-64-12-2577

Cavanagh D (1991) Sequencing approach to IBV antigenicity and epizootiology. In: Proceedings of the second international symposium on infectious bronchitis, Rauischholzhausen, pp 147-160

Cavanagh D (2003) Severe acute respiratory syndrome vaccine development: experiences of vaccination against avian infectious bronchitis coronavirus. Avian Pathol 32(6):567-582. doi:10.1 080/03079450310001621198

Cavanagh D (2007) Coronavirus avian infectious bronchitis virus. Vet Res 38(2):281-297. doi:10.1051/vetres:2006055

Cavanagh D, Gelb JJ (2008) Infectious bronchitis. In: Saif YM, Fadly AM, Glisson JR, McDougald LR, Nolan MK, Swayne DE (eds) Diseases of poultry, 12th edn. Ames/Iowa, BlackWell, p 117-136

Cavanagh D, Davis PJ, Mockett AP (1988) Amino acids within hypervariable region 1 of avian coronavirus IBV (Massachusetts serotype) spike glycoprotein are associated with neutralization epitopes. Virus Res 11(2):141-150

Cavanagh D, Davis P, Cook J, Li D (1990) Molecular basis of the variation exhibited by avian infectious bronchitis coronavirus (IBV). Adv Exp Med Biol 276:369-372

Cavanagh D, Davis P, Cook JK, Li D, Kant A, Koch G (1992a) Location of the amino acid differences in the S1 spike glycoprotein subunit of closely related serotypes of infectious bronchitis virus. Avian Pathol 21(1):33-43 
Cavanagh D, Davis PJ, Cook JK (1992b) Infectious bronchitis virus: evidence for recombination within the Massachusetts serotype. Avian Pathol 21(3):401-408. doi:10.1080/03079459208418858

Cavanagh D, Elus MM, Cook JK (1997) Relationship between sequence variation in the S1 spike protein of infectious bronchitis virus and the extent of cross-protection in vivo. Avian Pathol 26(1):63-74. doi:10.1080/03079459708419194

Cavanagh D, Picault JP, Gough R, Hess M, Mawditt K, Britton P (2005) Variation in the spike protein of the 793/B type of infectious bronchitis virus, in the field and during alternate passage in chickens and embryonated eggs. Avian Pathol34(1):20-25. doi:10.1080/03079450400025414

Chen BY, Itakura C (1996) Cytopathology of chick renal epithelial cells experimentally infected with avian infectious bronchitis virus. Avian Pathol 25(4):675-690. doi:10.1080/03079459608419174

Chen HW, Huang YP, Wang CH (2009) Identification of Taiwan and China-like recombinant avian infectious bronchitis viruses in Taiwan. Virus Res 140(1-2):121-129. doi:10.1016/j. virusres.2008.11.012

Chew PH, Wakenell PS, Farver TB (1997) Pathogenicity of attenuated infectious bronchitis viruses for oviducts of chickens exposed in ovo. Avian Dis 41(3):598-603

Chhabra R, Chantrey J, Ganapathy K (2015) Immune responses to virulent and vaccine strains of infectious bronchitis viruses in chickens. Viral Immunol. doi:10.1089/vim.2015.0027

Chu VC, McElroy LJ, Chu V, Bauman BE, Whittaker GR (2006) The avian coronavirus infectious bronchitis virus undergoes direct low-pH-dependent fusion activation during entry into host cells. J Virol 80(7):3180-3188. doi:10.1128/jvi.80.7.3180-3188.2006

Collisson EW, Li JZ, Sneed LW, Peters ML, Wang L (1990) Detection of avian infectious bronchitis viral infection using in situ hybridization and recombinant DNA. Vet Microbiol 24(3-4):261-271

Collisson EW, Pei J, Dzielawa J, Seo SH (2000) Cytotoxic T lymphocytes are critical in the control of infectious bronchitis virus in poultry. Dev Comp Immunol 24(2-3):187-200

Cong F, Liu X, Han Z, Shao Y, Kong X, Liu S (2013) Transcriptome analysis of chicken kidney tissues following coronavirus avian infectious bronchitis virus infection. BMC Genomics 14:743. doi:10.1186/1471-2164-14-743

Cook JK (1968) Duration of experimental infectious bronchitis in chickens. Res Vet Sci 9(6):506-514

Cook JK, Darbyshire JH, Peters RW (1976) The use of chicken tracheal organ cultures for the isolation and assay of avian infectious bronchitis virus. Arch Virol 50(1-2):109-118

Cook JK, Orbell SJ, Woods MA, Huggins MB (1996) A survey of the presence of a new infectious bronchitis virus designated 4/91 (793B). Vet Rec 138(8):178-180

Cook JK, Chesher AJ, Baxendale W, Greenwood N, Huggins MB, Orbell SJ (2001) Protection of chickens against renal damage caused by a nephropathogenic infectious bronchitis virus. Avian Pathol 30:423-426

Corse E, Machamer CE (2003) The cytoplasmic tails of infectious bronchitis virus E and M proteins mediate their interaction. Virology 312(1):25-34

Crinion RA (1972) Egg quality and production following infectious bronchitis virus exposure at one day old. Poult Sci 51(2):582-585

Cumming RB (1970) Studies on Australian infectious bronchitis virus. IV. Apparent farm-to-farm airborne transmission of infectious bronchitis virus. Avian Dis 14(1):191-195

Cunningham C (1973) A laboratory guide in virology. 7th edn. Burgess, Minneapolis, p 67-80

Cunningham CH, El Dardiry A (1948) Distribution of the virus of infectious bronchitis of chickens in embryonated chicken eggs. Cornell Vet 38:381-388

Darbyshire JH (1980) Assessment of cross-immunity dm chickens to strains of avian infectious bronchitis virus using tracheal organ cultures. Avian Pathol 9(2):179-184. doi:10.1080/03079458008418401

Darbyshire JH (1985) A clearance test to assess protection in chickens vaccinated against avian infectious bronchitis virus. Avian Pathol 14(4):497-508. doi:10.1080/03079458508436252

Darbyshire JH, Rowell JG, Cook JK, Peters RW (1979) Taxonomic studies on strains of avian infectious bronchitis virus using neutralisation tests in tracheal organ cultures. Arch Virol 61(3):227-238 
Davelaar FG, Noordzij A, Vanderdonk JA (1982) A study on the synthesis and secretion of immunoglobulins by the Jarderian gland of the fowl after eyedrop vaccination against infectious bronchitis at 1-day-old. Avian Pathol 11(1):63-79. doi:10.1080/03079458208436082

Davelaar FG, Kouwenhoven B, Burger AG (1984) Occurrence and significance of infectious bronchitis virus variant strains in egg and broiler production in the Netherlands. Vet Q 6(3):114 120. doi:10.1080/01652176.1984.9693924

Dawson PS, Gough RE (1971) Antigenic variation in strains of avian infectious bronchitis virus. Arch Gesamte Virusforsch 34(1):32-39

de Haan CA, Masters PS, Shen X, Weiss S, Rottier PJ (2002) The group-specific murine coronavirus genes are not essential, but their deletion, by reverse genetics, is attenuating in the natural host. Virology 296(1):177-189. doi:10.1006/viro.2002.1412

De Wit J, Davelaar F, Braunius W (1992) Comparison of the enzyme linked immunosorbent assay, the haemagglutination inhibition test and the agar gel precipitation test for the detection of antibodies against infectious bronchitis and Newcastle disease in commercial broilers. Avian Pathol 21(4):651-658

De Wit JJ, Koch G, Kant A, Van Roozelaar DJ (1995) Detection by immunofluorescent assay of serotype-specific and group-specific antigens of infectious bronchitis virus in tracheas of broilers with respiratory problems. Avian Pathol 24(3):465-474. doi:10.1080/03079459508419086

De Wit J, Mekkes D, Kouwenhoven B, Verheijden J (1997) Sensitivity and specificity of serological tests for infectious bronchitis virus antibodies in broilers. Avian Pathol 26(1):105-118

De Wit JJ, Brandao P, Torres CA, Koopman R, Villarreal LY (2015) Increased level of protection of respiratory tract and kidney by combining different infectious bronchitis virus vaccines against challenge with nephropathogenic Brazilian genotype subcluster 4 strains. Avian Pathol 44(5):352-357. doi:10.1080/03079457.2015.1058916

Delaplane J (1947) Technique for the isolation of infec tious bronchitis or Newcastle virus including observa tions on the use of streptomycin in overcoming bacterial contaminants. In: NE. Conf. Lab. Workers Pullorum Dis. Control Proc. 19, p 11-13

Delmas B, Laude H (1990) Assembly of coronavirus spike protein into trimers and its role in epitope expression. J Virol 64(11):5367-5375

Dhinakar Raj G, Jones RC (1996) Protectotypic differentiation of avian infectious bronchitis viruses using an in vitro challenge model. Vet Microbiol 53(3-4):239-252

Ducatez MF, Martin AM, Owoade AA, Olatoye IO, Alkali BR, Maikano I, Snoeck CJ, Sausy A, Cordioli P, Muller CP (2009) Characterization of a new genotype and serotype of infectious bronchitis virus in Western Africa. J Gen Virol 90(Pt 11):2679-2685. doi:10.1099/vir.0.012476-0

Elankumaran S, Balachandran C, Chandran ND, Roy P, Albert A, Manickam R (1999) Serological evidence for a 793/B related avian infectious bronchitis virus in India. Vet Rec 144(11):299-300

El-Kady MF (1989) Studies on the epidemiology and means of control of infectious bronchitis disease in chickens in Egypt. Faculty of Veterinary Medicine, Egypt

Escorcia M, Jackwood MW, Lucio B, Petrone VM, Lopez C, Fehervari T, Tellez G (2000) Characterization of Mexican strains of avian infectious bronchitis isolated during 1997. Avian Dis 44(4):944-947

Fang S, Shen H, Wang J, Tay FP, Liu DX (2010) Functional and genetic studies of the substrate specificity of coronavirus infectious bronchitis virus 3C-like proteinase. J Virol 84(14):73257336. doi:10.1128/jvi.02490-09

Fellahi S, El Harrak M, Ducatez M, Loutfi C, Koraichi SI, Kuhn JH, Khayi S, El Houadfi M, Ennaji MM (2015) Phylogenetic analysis of avian infectious bronchitis virus S1 glycoprotein regions reveals emergence of a new genotype in Moroccan broiler chicken flocks. Virol J 12:116. doi:10.1186/s12985-015-0347-8

Feng K, Xue Y, Wang J, Chen W, Chen F, Bi Y, Xie Q (2015) Development and efficacy of a novel live-attenuated QX-like nephropathogenic infectious bronchitis virus vaccine in China. Vaccine 33(9):1113-1120. doi:10.1016/j.vaccine.2015.01.036

Fulton RM, Thacker HL, Reed WM, DeNicola DB (1997) Effect of cytoxan-induced heteropenia on the response of specific-pathogen-free chickens to infectious bronchitis. Avian Dis 41(3):511-518 
Garcia Z, Bankowski R (1981) Comparison of a tissue-culture virus-neutralization test and the enzyme-linked immunosorbent assay for measurement of antibodies to infectious bronchitis. Avian Dis 25:121-130

Gelb J Jr (1989) Infectious bronchitis. A laboratory manual for the isolation and identification of avian pathogens, 3rd edn, Dubuque Iowa, Kendall/Hunt Publishing Co, 124-127

Gelb J Jr, Keeler CL Jr, Nix WA, Rosenberger JK, Cloud SS (1997) Antigenic and S-1 genomic characterization of the Delaware variant serotype of infectious bronchitis virus. Avian Dis 41(3):661-669

Gelb J Jr, Nix WA, Gellman SD (1998) Infectious bronchitis virus antibodies in tears and their relationship to immunity. Avian Dis 42(2):364-374

Gelb J Jr, Ladman BS, Tamayo M, Gonzalez M, Sivanandan V (2001) Novel infectious bronchitis virus S1 genotypes in Mexico 1998-1999. Avian Dis 45(4):1060-1063

Gelb J Jr, Weisman Y, Ladman BS, Meir R (2005) S1 gene characteristics and efficacy of vaccination against infectious bronchitis virus field isolates from the United States and Israel (1996 to 2000). Avian Pathol 34(3):194-203. doi:10.1080/03079450500096539

GenCheng P, YiHai J, YongLing W, YuDong W, ZiChun Z, Jiang D, XiangE L, YinLin Y, YuXiang O, FuYong W (1998) Isolation and identification of glandular stomach-pathogenic type infectious bronchitis virus in Beijing area. Chin J Vet Sci Technol 28(10):21-22

Gentry RF, Braune MO (1972) Prevention of virus inactivation during drinking water vaccination of poultry. Poult Sci 51(4):1450-1456

Godet M, L'Haridon R, Vautherot JF, Laude H (1992) TGEV corona virus ORF4 encodes a membrane protein that is incorporated into virions. Virology 188(2):666-675

Gonzalez JM, Gomez-Puertas P, Cavanagh D, Gorbalenya AE, Enjuanes L (2003) A comparative sequence analysis to revise the current taxonomy of the family Coronaviridae. Arch Virol 148(11):2207-2235. doi:10.1007/s00705-003-0162-1

Gough R, Alexander D (1977) Comparison of serological tests for the measurement of the primary immune response to avian infectious bronchitis virus vaccines. Vet Microbiol 2(4):289-301

Gough RE, Alexander DJ (1979) Comparison of duration of immunity in chickens infected with a live infectious bronchitis vaccine by three different routes. Res Vet Sci 26(3):329-332

Gough RE, Allan WH, Nedelciu D (1977) Immune response to monovalent and bivalent Newcastle disease and infectious bronchitis inactivated vaccines. Avian Pathol 6(2):131-142. doi:10.1080/03079457708418221

Gough RE, Randall CJ, Dagless M, Alexander DJ, Cox WJ, Pearson D (1992) A 'new' strain of infectious bronchitis virus infecting domestic fowl in Great Britain. Vet Rec 130(22):493-494

Guo X, Rosa AJ, Chen DG, Wang X (2008) Molecular mechanisms of primary and secondary mucosal immunity using avian infectious bronchitis virus as a model system. Vet Immunol Immunopathol 121(3-4):332-343. doi:10.1016/j.vetimm.2007.09.016

Guo Z, Wang H, Yang T, Wang X, Lu D, Li Y, Zhang Y (2010) Priming with a DNA vaccine and boosting with an inactivated vaccine enhance the immune response against infectious bronchitis virus. J Virol Methods 167(1):84-89. doi:10.1016/j.jviromet.2010.03.016

Han Z, Sun C, Yan B, Zhang X, Wang Y, Li C, Zhang Q, Ma Y, Shao Y, Liu Q, Kong X, Liu S (2011) A 15-year analysis of molecular epidemiology of avian infectious bronchitis coronavirus in China. Infect Genet Evol J Mol Epidemiol Evol Genet Infect Dis 11(1):190-200. doi:10.1016/j.meegid.2010.09.002

Handberg K, Nielsen O, Pedersen M, JØrgensen PH (1999) Detection and strain differentiation of infectious bronchitis virus in tracheal tissues from experimentally infected chickens by reverse transcription-polymerase chain reaction. Comparison with an immunohistochemical technique. Avian Pathol 28 (4):327-335

Hewson KA, Noormohammadi AH, Devlin JM, Browning GF, Schultz BK, Ignjatovic J (2014) Evaluation of a novel strain of infectious bronchitis virus emerged as a result of spike gene recombination between two highly diverged parent strains. Avian Pathol 43(3):249-257. doi:1 0.1080/03079457.2014.914624

Hinze V, Lohr J, Kaleta E (1991) Infectious bronchitis virus strain differentiation attempts by cross-immunity studies in tracheal organ cultures derived from immunised chickens. In: Proc. 
of the 2nd Int. Symp. on Infectious Bronchitis. World's Poultry Science Association, European group no. 7 Rauischholzhausen, pp 73-86

Hodgson T, Casais R, Dove B, Britton P, Cavanagh D (2004) Recombinant infectious bronchitis coronavirus Beaudette with the spike protein gene of the pathogenic M41 strain remains attenuated but induces protective immunity. J Virol 78(24):13804-13811. doi:10.1128/ jvi.78.24.13804-13811.2004

Hofstad M, Yoder HW (1966) Avian infectious bronchitis: virus distribution in tissues of chicks. Avian Dis 10(2):230-239

Hopkins SR (1974) Serological comparisons of strains of infectious bronchitis virus using plaquepurified isolants. Avian Dis 18(2):231-239

Hopkins SR, Yoder HW Jr (1986) Reversion to virulence of chicken-passaged infectious bronchitis vaccine virus. Avian Dis 30(1):221-223

Ignjatovic J, McWaters PG (1991) Monoclonal antibodies to three structural proteins of avian infectious bronchitis virus: characterization of epitopes and antigenic differentiation of Australian strains. J Gen Virol 72(Pt 12):2915-2922. doi:10.1099/0022-1317-72-12-2915

Ignjatovic J, Gould G, Sapats S (2006) Isolation of a variant infectious bronchitis virus in Australia that further illustrates diversity among emerging strains. Arch Virol 151(8):1567-1585. doi:10.1007/s00705-006-0726-y

Ivanov KA, Hertzig T, Rozanov M, Bayer S, Thiel V, Gorbalenya AE, Ziebuhr J (2004) Major genetic marker of nidoviruses encodes a replicative endoribonuclease. Proc Natl Acad Sci U S A 101(34):12694-12699. doi:10.1073/pnas.0403127101

Jackwood MW (2012) Review of infectious bronchitis virus around the world. Avian Dis 56(4):634-641. doi:10.1637/10227-043012-Review.1

Jackwood MW, Hilt DA, Lee CW, Kwon HM, Callison SA, Moore KM, Moscoso H, Sellers H, Thayer S (2005) Data from 11 years of molecular typing infectious bronchitis virus field isolates. Avian Dis 49(4):614-618. doi:10.1637/7389-052905r.1

Jackwood MW, Hilt DA, Williams SM, Woolcock P, Cardona C, O'Connor R (2007) Molecular and serologic characterization, pathogenicity, and protection studies with infectious bronchitis virus field isolates from California. Avian Dis 51(2):527-533. doi:10.1637/00052086(2007)51[527:mascpa]2.0.co;2

Jackwood MW, Boynton TO, Hilt DA, McKinley ET, Kissinger JC, Paterson AH, Robertson J, Lemke C, McCall AW, Williams SM, Jackwood JW, Byrd LA (2010a) Emergence of a group 3 coronavirus through recombination. Virology 398(1):98-108. doi:10.1016/j. virol.2009.11.044

Jackwood MW, Hilt DA, Sellers HS, Williams SM, Lasher HN (2010b) Rapid heat-treatment attenuation of infectious bronchitis virus. Avian Pathol 39(3):227-233. doi:10.1080/03079451003801516

Jang H, Koo BS, Jeon EO, Lee HR, Lee SM, Mo IP (2013) Altered pro-inflammatory cytokine mRNA levels in chickens infected with infectious bronchitis virus. Poult Sci 92(9):2290-2298. doi: $10.3382 /$ ps.2013-03116

Jayaram J, Youn S, Collisson EW (2005) The virion N protein of infectious bronchitis virus is more phosphorylated than the N protein from infected cell lysates. Virology 339(1):127-135. doi:10.1016/j.virol.2005.04.029

Jia W, Karaca K, Parrish CR, Naqi SA (1995) A novel variant of avian infectious bronchitis virus resulting from recombination among three different strains. Arch Virol 140(2):259-271

Jia W, Wang X, Parrish CR, Naqi SA (1996) Analysis of the serotype-specific epitopes of avian infectious bronchitis virus strains Ark99 and Mass41. J Virol 70(10):7255-7259

Johnson MA, Pooley C, Ignjatovic J, Tyack SG (2003) A recombinant fowl adenovirus expressing the $\mathrm{S} 1$ gene of infectious bronchitis virus protects against challenge with infectious bronchitis virus. Vaccine 21(21-22):2730-2736

Jones R, Ambali A (1987) Re-excretion of an enterotropic infectious bronchitis virus by hens at point of lay after experimental infection at day old. Vet Rec 120(26):617-618

Jones RC, Worthington KJ, Gough RE (2005) Detection of the Italy O2 strain of infectious bronchitis virus in the UK. Vet Rec 156(8):260 
Juul-Madsen HR, Norup LR, Handberg KJ, Jorgensen PH (2007) Mannan-binding lectin (MBL) serum concentration in relation to propagation of infectious bronchitis virus (IBV) in chickens. Viral Immunol 20(4):562-570. doi:10.1089/vim.2007.0036

Kant A, Koch G, van Roozelaar DJ, Kusters JG, Poelwijk FA, van der Zeijst BA (1992) Location of antigenic sites defined by neutralizing monoclonal antibodies on the S1 avian infectious bronchitis virus glycopolypeptide. J Gen Virol 73(Pt 3):591-596. doi:10.1099/0022-1317-73-3-591

Karaca K, Syed N (1993) A monoclonal antibody blocking ELISA to detect serotype-specific infectious bronchitis virus antibodies. Vet Microbiol 34(3):249-257

Karaca K, Naqi S, Gelb J Jr (1992) Production and characterization of monoclonal antibodies to three infectious bronchitis virus serotypes. Avian Dis 36(4):903-915

Kaufhold C, Lohr JE, Kosters J (1988) Comparison of serum neutralization and haemagglutination inhibition tests for various serotypes of avian infectious bronchitis virus. Tierarztl Umsch 45:595-600

Keeler CL Jr, Reed KL, Nix WA, Gelb J Jr (1998) Serotype identification of avian infectious bronchitis virus by RT-PCR of the peplomer (S-1) gene. Avian Dis 42(2):275-284

King DJ, Hopkins SR (1984) Rapid serotyping of infectious bronchitis virus isolates with the hemagglutination-inhibition test. Avian Dis 28(3):727-733

Kingham BF, Keeler CL Jr, Nix WA, Ladman BS, Gelb J Jr (2000) Identification of avian infectious bronchitis virus by direct automated cycle sequencing of the S-1 gene. Avian Dis 44(2):325-335

Klieve AV, Cumming RB (1988) Immunity and cross-protection to nephritis produced by Australian infectious bronchitis viruses used as vaccines. Avian Pathol 17(4):829-839. doi:10.1080/03079458808436505

Klumperman J, Locker JK, Meijer A, Horzinek MC, Geuze HJ, Rottier PJ (1994) Coronavirus M proteins accumulate in the Golgi complex beyond the site of virion budding. J Virol 68(10):6523-6534

Knoetze AD, Moodley N, Abolnik C (2014) Two genotypes of infectious bronchitis virus are responsible for serological variation in KwaZulu-Natal poultry flocks prior to 2012. Onderstepoort J Vet Res 81(1). doi:10.4102/ojvr.v81i1.769

Koch G, Hartog L, Kant A, van Roozelaar DJ (1990) Antigenic domains on the peplomer protein of avian infectious bronchitis virus: correlation with biological functions. J Gen Virol 71(Pt 9):1929-1935. doi:10.1099/0022-1317-71-9-1929

Koch G, Kant A, Cook J, Cavanagh D (1991) Epitopes of neutralizing antibodies are localized within three regions of the S1 spike protein of infectious bronchitis virus. In: International Symposium of Infectious Bronchitis, World Veterinary Poultry Association, Rauischholzhausen, pp 154-160

Kuo L, Masters PS (2002) Genetic evidence for a structural interaction between the carboxy termini of the membrane and nucleocapsid proteins of mouse hepatitis virus. J Virol 76(10):4987-4999

Kuo SM, Wang CH, Hou MH, Huang YP, Kao HW, Su HL (2010) Evolution of infectious bronchitis virus in Taiwan: characterisation of RNA recombination in the nucleocapsid gene. Vet Microbiol 144(3-4):293-302. doi:10.1016/j.vetmic.2010.02.027

Kusters JG, Niesters HG, Lenstra JA, Horzinek MC, van der Zeijst BA (1989) Phylogeny of antigenic variants of avian coronavirus IBV. Virology 169(1):217-221

Kwon HM, Jackwood MW, Gelb J Jr (1993) Differentiation of infectious bronchitis virus serotypes using polymerase chain reaction and restriction fragment length polymorphism analysis. Avian Dis 37:194-202

Lai MM, Cavanagh D (1997) The molecular biology of coronaviruses. Adv Virus Res 48:1-100

Lambrechts C, Pensaert M, Ducatelle R (1993) Challenge experiments to evaluate cross-protection induced at the trachea and kidney level by vaccine strains and Belgian nephropathogenic isolates of avian infectious bronchitis virus. Avian Pathol 22(3):577-590. doi:10.1080/03079459308418945

Lee CW, Jackwood MW (2000) Evidence of genetic diversity generated by recombination among avian coronavirus IBV. Arch Virol 145(10):2135-2148 
Lee CW, Hilt DA, Jackwood MW (2001) Identification and analysis of the Georgia 98 serotype, a new serotype of infectious bronchitis virus. Avian Dis 45(1):164-172

Lee HJ, Youn HN, Kwon JS, Lee YJ, Kim JH, Lee JB, Park SY, Choi IS, Song CS (2010) Characterization of a novel live attenuated infectious bronchitis virus vaccine candidate derived from a Korean nephropathogenic strain. Vaccine 28(16):2887-2894. doi:10.1016/j. vaccine.2010.01.062

Lewicki DN, Gallagher TM (2002) Quaternary structure of coronavirus spikes in complex with carcinoembryonic antigen-related cell adhesion molecule cellular receptors. J Biol Chem 277(22):19727-19734. doi:10.1074/jbc.M201837200

Li H, Yang H (2001) Sequence analysis of nephropathogenic infectious bronchitis virus strains of the Massachusetts genotype in Beijing. Avian Pathol 30(5):535-541. doi:10.1080/03079450120078734

Lim TH, Kim MS, Jang JH, Lee DH, Park JK, Youn HN, Lee JB, Park SY, Choi IS, Song CS (2012) Live attenuated nephropathogenic infectious bronchitis virus vaccine provides broad cross protection against new variant strains. Poult Sci 91(1):89-94. doi:10.3382/ ps.2011-01739

Lin Z, Kato A, Kudou Y, Ueda S (1991) A new typing method for the avian infectious bronchitis virus using polymerase chain reaction and restriction enzyme fragment length polymorphism. Arch Virol 116(1-4):19-31

Liu S, Chen J, Chen J, Kong X, Shao Y, Han Z, Feng L, Cai X, Gu S, Liu M (2005) Isolation of avian infectious bronchitis coronavirus from domestic peafowl (Pavo cristatus) and teal (Anas). J Gen Virol 86(3):719-725

Liu X, Shao Y, Ma H, Sun C, Zhang X, Li C, Han Z, Yan B, Kong X, Liu S (2013) Comparative analysis of four Massachusetts type infectious bronchitis coronavirus genomes reveals a novel Massachusetts type strain and evidence of natural recombination in the genome. Infect Genet Evol J Mol Epidemiol Evol Genet Infect Dis 14:29-38. doi:10.1016/j.meegid.2012.09.016

Lohr J (1988) Differentiation of IBV strains. In: Proceedings of the 1st International Symposium on Infectious Bronchitis. Deutsche Veterinarmedizinische Gesellschaft eV, Giessen, pp 199-207

Ma H, Shao Y, Sun C, Han Z, Liu X, Guo H, Liu X, Kong X, Liu S (2012) Genetic diversity of avian infectious bronchitis coronavirus in recent years in China. Avian Dis 56(1):15-28. doi:10.1637/9804-052011-Reg.1

Macdonald JW, Randall CJ, McMartin DA, Dagless MD (1981) Immunity following vaccination with the H120 strain of infectious bronchitis virus via the drinking water. Avian Pathol 10(3):295-301. doi:10.1080/03079458108418478

Madbouly HM, Abdel-Moneim AS, Gelb JJ, Ladman BS, Rofael NB (2002) Molecular characterization of three Egyptian infectious bronchitis virus isolates. Vet Med 50(4):1053-1064

Maeda J, Maeda A, Makino S (1999) Release of coronavirus E protein in membrane vesicles from virus-infected cells and E protein-expressing cells. Virology 263(2):265-272. doi:10.1006/ viro.1999.9955

Maeda J, Repass JF, Maeda A, Makino S (2001) Membrane topology of coronavirus E protein. Virology 281(2):163-169. doi:10.1006/viro.2001.0818

Mahmood ZH, Sleman RR, Uthman AU (2011) Isolation and molecular characterization of Sul/01/09 avian infectious bronchitis virus, indicates the emergence of a new genotype in the Middle East. Vet Microbiol 150(1-2):21-27. doi:10.1016/j.vetmic.2010.12.015

Mardani K, Noormohammadi AH, Hooper P, Ignjatovic J, Browning GF (2008) Infectious bronchitis viruses with a novel genomic organization. J Virol 82(4):2013-2024. doi:10.1128/jvi.01694-07

Mardani K, Noormohammadi AH, Ignjatovic J, Browning GF (2010) Naturally occurring recombination between distant strains of infectious bronchitis virus. Arch Virol 155(10):1581-1586. doi:10.1007/s00705-010-0731-z

Marquardt W, Snyder D, Schlotthober B (1981) Detection and quantification of antibodies to infectious bronchitis virus by enzyme-linked immunosorbent assay. Avian Dis 25:713-722

Martin EA, Brash ML, Hoyland SK, Coventry JM, Sandrock C, Guerin MT, Ojkic D (2014) Genotyping of infectious bronchitis viruses identified in Canada between 2000 and 2013. Avian Pathol 43(3):264-268. doi:10.1080/03079457.2014.916395 
Masters P, Perlman S (2013) Coronaviridae. In: Howley P, Knipe DM (eds) Fields of virology. Kluwer, Wolters

Masters PS (2006) The molecular biology of coronaviruses. Adv Virus Res 66:193-292. doi:10.1016/s0065-3527(06)66005-3

McFarlane R, Verma R (2008) Sequence analysis of the gene coding for the S1 glycoprotein of infectious bronchitis virus (IBV) strains from New Zealand. Virus Genes 37(3):351-357. doi:10.1007/s11262-008-0273-6

McKinley ET, Hilt DA, Jackwood MW (2008) Avian coronavirus infectious bronchitis attenuated live vaccines undergo selection of subpopulations and mutations following vaccination. Vaccine 26(10):1274-1284. doi:10.1016/j.vaccine.2008.01.006

McMartin DA (1993) Infectious bronchitis. Virus infections of vertebrates virus infections of birds, vol 4. Elsevier Science Publishers, Amsterdam/New York, pp 249-275

Mihindukulasuriya KA, Wu G, St Leger J, Nordhausen RW, Wang D (2008) Identification of a novel coronavirus from a beluga whale by using a panviral microarray. J Virol 82(10):50845088. doi:10.1128/jvi.02722-07

Minskaia E, Hertzig T, Gorbalenya AE, Campanacci V, Cambillau C, Canard B, Ziebuhr J (2006) Discovery of an RNA virus 3'- > 5' exoribonuclease that is critically involved in coronavirus RNA synthesis. Proc Natl Acad Sci U S A 103(13):5108-5113. doi:10.1073/pnas.0508200103

Mockett AP, Cavanagh D, Brown TD (1984) Monoclonal antibodies to the S1 spike and membrane proteins of avian infectious bronchitis coronavirus strain Massachusetts M41. J Gen Virol 65(Pt 12):2281-2286. doi:10.1099/0022-1317-65-12-2281

Mondal SP, Cardona CJ (2007) Genotypic and phenotypic characterization of the California 99 (Cal99) variant of infectious bronchitis virus. Virus Genes 34(3):327-341. doi:10.1007/ s11262-006-0014-7

Mondal SP, Naqi SA (2001) Maternal antibody to infectious bronchitis virus: its role in protection against infection and development of active immunity to vaccine. Vet Immunol Immunopathol 79(1-2):31-40

Nakamura K, Cook JK, Otsuki K, Huggins MB, Frazier JA (1991) Comparative study of respiratory lesions in two chicken lines of different susceptibility infected with infectious bronchitis virus: histology, ultrastructure and immunohistochemistry. Avian Pathol 20(2):241-257. doi: $10.1080 / 03079459108418761$

Naqi SA (1990) A monoclonal antibody-based immunoperoxidase procedure for rapid detection of infectious bronchitis virus in infected tissues. Avian Dis 34(4):893-898

Narayanan K, Chen CJ, Maeda J, Makino S (2003) Nucleocapsid-independent specific viral RNA packaging via viral envelope protein and viral RNA signal. J Virol 77(5):2922-2927

Niesters HG, Bleumink-Pluym NM, Osterhaus AD, Horzinek MC, van der Zeijst BA (1987a) Epitopes on the peplomer protein of infectious bronchitis virus strain M41 as defined by monoclonal antibodies. Virology 161(2):511-519

Niesters HG, Kusters JG, Lenstra JA, Spaan WJ, Horzined MC, van der Zeijst BA (1987b) The neutralization epitopes on the spike protein of infectious bronchitis virus and their antigenic variation. Adv Exp Med Biol 218:483-492

OIE (2013) Avian infectious bronchitis virus. Terrestrial Manual. Chapter 2.3.2., pp. 1-15.

Okino CH, dos Santos IL, Fernando FS, Alessi AC, Wang X, Montassier HJ (2014) Inflammatory and cell-mediated immune responses in the respiratory tract of chickens to infection with avian infectious bronchitis virus. Viral Immunol 27(8):383-391. doi:10.1089/vim.2014.0054

Orr-Burks N, Gulley SL, Toro H, van Ginkel FW (2014) Immunoglobulin A as an early humoral responder after mucosal avian coronavirus vaccination. Avian Dis 58(2):279-286. doi:10.1637/10740-120313-Reg.1

Otsuki K, Nakamura T, Kubota N, Kawaoka Y, Tsubokura M (1987) Comparison of two strains of avian infectious bronchitis virus for their interferon induction, viral growth and development of virus-neutralizing antibody in experimentally-infected chickens. Vet Microbiol 15(1-2):31-40

Ovchinnikova EV, Bochkov YA, Shcherbakova LO, Nikonova ZB, Zinyakov NG, Elatkin NP, Mudrak NS, Borisov AV, Drygin VV (2011) Molecular characterization of infectious bronchitis virus isolates from Russia and neighbouring countries: identification of intertypic recombination in the S1 gene. Avian Pathol 40(5):507-514. doi:10.1080/03079457.2011.605782 
Pasternak AO, Spaan WJ, Snijder EJ (2006) Nidovirus transcription: how to make sense...? J Gen Virol 87(Pt 6):1403-1421. doi:10.1099/vir.0.81611-0

Pensaert M, Lambrechts C (1994) Vaccination of chickens against a Belgian nephropathogenic strain of infectious bronchitis virus B1648 using attenuated homologous and heterologous strains. Avian Pathol 23(4):631-641. doi:10.1080/03079459408419033

Pohuang T, Chansiripornchai N, Tawatsin A, Sasipreeyajan J (2011) Sequence analysis of S1 genes of infectious bronchitis virus isolated in Thailand during 2008-2009: identification of natural recombination in the field isolates. Virus Genes 43(2):254-260. doi:10.1007/ s11262-011-0635-3

Promkuntod N, Thongmee S, Yoidam S (2015) Analysis of the S1 gene of the avian infectious bronchitis virus (IBV) reveals changes in the IBV genetic groups circulating in southern Thailand. Res Vet Sci 100:299-302. doi: 10.1016/j.rvsc.2015.05.002

Promkuntod N, van Eijndhoven RE, de Vrieze G, Grone A, Verheije MH (2014) Mapping of the receptor-binding domain and amino acids critical for attachment in the spike protein of avian coronavirus infectious bronchitis virus. Virology 448:26-32. doi:10.1016/j.virol.2013.09.018

Quiroz M, Retana A, Tamayo M (1993) Determinacion de la presencia del serotipe Arkansas a partir de aislamintos del virus de bronquitos infecciosa aviar en Mexico. Jornada Medico Avicola Coyoacan Mexico 4:191-198

Raamsman MJ, Locker JK, de Hooge A, de Vries AA, Griffiths G, Vennema H, Rottier PJ (2000) Characterization of the coronavirus mouse hepatitis virus strain A59 small membrane protein E. J Virol 74(5):2333-2342

Raggi LG, Lee GG (1965) Lack of correlation between infectivity, serologic response and challenge results in immunization with an avian infectious bronchitis vaccine. J Immunol (Baltimore, Md : 1950) 94:538-543

Raj GD, Jones RC (1997) Infectious bronchitis virus: Immunopathogenesis of infection in the chicken. Avian Pathol 26(4):677-706. doi:10.1080/03079459708419246

Raj GD, Savage CE, Jones RC (1997) Effect of heterophil depletion by 5-fluorouracil on infectious bronchitisvirusinfectioninchickens.AvianPathol26(2):427-432.doi:10.1080/03079459708419224

Reddy VR, Theuns S, Roukaerts ID, Zeller M, Matthijnssens J, Nauwynck HJ (2015) Genetic Characterization of the Belgian Nephropathogenic Infectious Bronchitis Virus (NIBV) Reference Strain B1648. Viruses 7(8):4488-4506. doi:10.3390/v7082827

Rimondi A, Craig MI, Vagnozzi A, Konig G, Delamer M, Pereda A (2009) Molecular characterization of avian infectious bronchitis virus strains from outbreaks in Argentina (2001-2008). Avian Pathol 38(2):149-153. doi:10.1080/03079450902737821

Ruano M, El-Attrache J, Villegas P (2000) A rapid-plate hemagglutination assay for the detection of infectious bronchitis virus. Avian Dis 44(1):99-104

Sawicki SG, Sawicki DL (1990) Coronavirus transcription: subgenomic mouse hepatitis virus replicative intermediates function in RNA synthesis. J Virol 64(3):1050-1056

Sawicki SG, Sawicki DL (1995) Coronaviruses use discontinuous extension for synthesis of subgenome-length negative strands. Adv Exp Med Biol 380:499-506

Sawicki SG, Sawicki DL (2005) Coronavirus transcription: a perspective. Curr Top Microbiol Immunol 287:31-55

Schalk A, Hawn M (1931) An apparently new respiratory disease of baby chicks. J Am Vet Med Assoc 78(413-422):19

Schultze B, Cavanagh D, Herrler G (1992) Neuraminidase treatment of avian infectious bronchitis coronavirus reveals a hemagglutinating activity that is dependent on sialic acid-containing receptors on erythrocytes. Virology 189(2):792-794

Seo SH, Pei J, Briles WE, Dzielawa J, Collisson EW (2000) Adoptive transfer of infectious bronchitis virus primed alphabeta $\mathrm{T}$ cells bearing $\mathrm{CD} 8$ antigen protects chicks from acute infection. Virology 269(1):183-189. doi:10.1006/viro.2000.0211

Seo SH, Wang L, Smith R, Collisson EW (1997) The carboxyl-terminal 120-residue polypeptide of infectious bronchitis virus nucleocapsid induces cytotoxic $\mathrm{T}$ lymphocytes and protects chickens from acute infection. J Virol 71(10):7889-7894

Sethna PB, Hung SL, Brian DA (1989) Coronavirus subgenomic minus-strand RNAs and the potential for mRNA replicons. Proc Natl Acad Sci U S A 86(14):5626-5630 
Sevoian M, Levine P (1957) Effects of infectious bronchitis on the reproductive tracts, egg production, and egg quality of laying chickens. Avian Dis 1(2):136-164

Shi XM, Zhao Y, Gao HB, Jing Z, Wang M, Cui HY, Tong GZ, Wang YF (2011) Evaluation of recombinant fowlpox virus expressing infectious bronchitis virus $\mathrm{S} 1$ gene and chicken interferon-gamma gene for immune protection against heterologous strains. Vaccine 29(8):1576-1582. doi:10.1016/j.vaccine.2010.12.102

Sigrist B, Tobler K, Schybli M, Konrad L, Stockli R, Cattoli G, Luschow D, Hafez HM, Britton P, Hoop RK, Vogtlin A (2012) Detection of Avian coronavirus infectious bronchitis virus type QX infection in Switzerland. J Vet Diagn Invest 24(6):1180-1183. doi:10.1177/1040638712463692

Snijder EJ, Bredenbeek PJ, Dobbe JC, Thiel V, Ziebuhr J, Poon LL, Guan Y, Rozanov M, Spaan WJ, Gorbalenya AE (2003) Unique and conserved features of genome and proteome of SARScoronavirus, an early split-off from the coronavirus group 2 lineage. J Mol Biol 331(5):991-1004

Snyder D, Marquardt W, Mallinson E, Allen D, Savage P (1985) An enzyme-linked immunosorbent assay method for the simultaneous measurement of antibody titer to multiple viral, bacterial or protein antigens. Vet Immunol Immunopathol 9(4):303-317

Snyder D, Marquardt W, Mallinson E, Russek E (1983a) Rapid serological profiling by enzymelinked immunosorbent assay. I. Measurement of antibody activity titer against Newcastle disease virus in a single serum dilution. Avian Dis 27:161-170

Snyder D, Marquardt W, Russek E (1983b) Rapid serological profiling by enzyme-linked immunosorbent assay. II. Comparison of computational methods for measuring antibody titer in a single serum dilution. Avian Dis 27:474-484

Song JE, Jeong WG, Sung HW, Kwon HM (2013) Sequencing, phylogenetic analysis, and potential recombination events of infectious bronchitis viruses isolated in Korea. Virus Genes 46(2):371-374. doi:10.1007/s11262-012-0856-0

Soula A, Moreau Y (1981) Antigen requirements and specificity of a microplate enzyme-linked immunosorbent assay (ELISA) for detecting infectious bronchitis viral antibodies in chicken serum. Arch Virol 67(4):283-295

Sultan HA, Tantawi L, Youseif AI, Ahmed AAS (2004) Urolithiathis in white commercial egg laying chickens associated with an infectious bronchitis virus. Paper presented at the 6th Sci Conf Egyp Vet Poult Assoc, Giza, Egypt

Sumi V, Singh SD, Dhama K, Gowthaman V, Barathidasan R, Sukumar K (2012) Isolation and molecular characterization of infectious bronchitis virus from recent outbreaks in broiler flocks reveals emergence of novel strain in India. Tropl Anim Health Prod 44(7):1791-1795. doi:10.1007/s11250-012-0140-2

Tan YW, Hong W, Liu DX (2012) Binding of the 5'-untranslated region of coronavirus RNA to zinc finger CCHC-type and RNA-binding motif 1 enhances viral replication and transcription. Nucleic Acids Res 40(11):5065-5077. doi:10.1093/nar/gks165

Thor SW, Hilt DA, Kissinger JC, Paterson AH, Jackwood MW (2011) Recombination in avian gamma-coronavirus infectious bronchitis virus. Viruses 3(9):1777-1799. doi:10.3390/v3091777

Thornton DH, Muskett JC (1975) Effect of infectious bronchitis vaccination on the performance of live Newcastle disease vaccine. Vet Rec 96(21):467-468

Toffan A, Bonci M, Bano L, Bano L, Valastro V, Vascellari M, Capua I, Terregino C (2013a) Diagnostic and clinical observation on the infectious bronchitis virus strain Q1 in Italy. Vet Ital 49(4):347-355. doi:10.12834/VetIt.1303.01

Toffan A, Bonci M, Bano L, Valastro V, Vascellari M, Capua I, Terregino C (2013b) Diagnostic and clinical observation on the infectious bronchitis virus strain Q1 in Italy. Vet Ital 49(4):347-355

Ujike M, Taguchi F (2015) Incorporation of spike and membrane glycoproteins into coronavirus virions. Viruses 7(4):1700-1725. doi:10.3390/v7041700

van Eck JH (1983) Effects of experimental infection of fowl with EDS'76 virus, infectious bronchitis virus and/or fowl adenovirus on laying performance. Vet Q 5(1):11-25. doi:10.1080/016 52176.1983.9693868

Vandekerchove D, Herdt PD, Laevens H, Butaye P, Meulemans G, Pasmans F (2004) Significance of interactions between Escherichia coli and respiratory pathogens in layer hen flocks suffering from colibacillosis-associated mortality. Avian Pathol 33(3):298-302 
Vennema H, Godeke GJ, Rossen JW, Voorhout WF, Horzinek MC, Opstelten DJ, Rottier PJ (1996) Nucleocapsid-independent assembly of coronavirus-like particles by co-expression of viral envelope protein genes. EMBO J 15(8):2020-2028

Verheije MH, Hagemeijer MC, Ulasli M, Reggiori F, Rottier PJ, Masters PS, de Haan CA (2010) The coronavirus nucleocapsid protein is dynamically associated with the replicationtranscription complexes. J Virol 84(21):11575-11579. doi:10.1128/jvi.00569-10

Wang L, Junker D, Collisson EW (1993) Evidence of natural recombination within the S1 gene of infectious bronchitis virus. Virology 192(2):710-716

Wei YQ, Guo HC, Dong H, Wang HM, Xu J, Sun DH, Fang SG, Cai XP, Liu DX, Sun SQ (2014) Development and characterization of a recombinant infectious bronchitis virus expressing the ectodomain region of S1 gene of H120 strain. Appl Microbiol Biotechnol 98(4):1727-1735. doi:10.1007/s00253-013-5352-5

Wickramasinghe IN, de Vries RP, Grone A, de Haan CA, Verheije MH (2011) Binding of avian coronavirus spike proteins to host factors reflects virus tropism and pathogenicity. J Virol 85(17):8903-8912. doi:10.1128/jvi.05112-11

Wilson L, Gage P, Ewart G (2006) Hexamethylene amiloride blocks E protein ion channels and inhibits coronavirus replication. Virology 353(2):294-306. doi:10.1016/j.virol.2006.05.028

Winter C, Herrler G, Neumann U (2008) Infection of the tracheal epithelium by infectious bronchitis virus is sialic acid dependent. Microbes Infect 10(4):367-373. doi:10.1016/j. micinf.2007.12.009

Winterfield RW, Hitchner SB (1962) Etiology of an infectious nephritis-nephrosis syndrome of chickens. Am J Vet Res 23:1273-1279

Woo PC, Huang Y, Lau SK, Yuen KY (2010) Coronavirus genomics and bioinformatics analysis. Viruses 2(8):1804-1820. doi:10.3390/v2081803

Woo PC, Lau SK, Lam CS, Lau CC, Tsang AK, Lau JH, Bai R, Teng JL, Tsang CC, Wang M, Zheng BJ, Chan KH, Yuen KY (2012) Discovery of seven novel Mammalian and avian coronaviruses in the genus deltacoronavirus supports bat coronaviruses as the gene source of alphacoronavirus and betacoronavirus and avian coronaviruses as the gene source of gammacoronavirus and deltacoronavirus. J Virol 86(7):3995-4008. doi:10.1128/jvi.06540-11

Worthington KJ, Currie RJ, Jones RC (2008) A reverse transcriptase-polymerase chain reaction survey of infectious bronchitis virus genotypes in Western Europe from 2002 to 2006. Avian Pathol 37(3):247-257. doi:10.1080/03079450801986529

Yachida S, Aoyama S, Sawaguchi K, Takahashi N, Iritani Y, Hayashi Y (1985) Relationship between several criteria of challenge-immunity and humoral immunity in chickens vaccinated with avian infectious bronchitis vaccines. Avian Pathol 14(2):199-211. doi:10.1080/03079458508436222

Yagyu K, Ohta S (1990) Detection of infectious bronchitis virus antigen from experimentally infected chickens by indirect immunofluorescent assay with monoclonal antibody. Avian Dis 34(2):246-252

Yu D, Han Z, Xu J, Shao Y, Li H, Kong X, Liu S (2010) A novel B-cell epitope of avian infectious bronchitis virus N protein. Viral Immunol 23(2):189-199. doi:10.1089/vim.2009.0094

Zhang J, Chen XW, Tong TZ, Ye Y, Liao M, Fan HY (2014) BacMam virus-based surface display of the infectious bronchitis virus (IBV) S1 glycoprotein confers strong protection against virulent IBV challenge in chickens. Vaccine 32(6):664-670. doi:10.1016/j. vaccine.2013.12.006

Zhang T, Han Z, Xu Q, Wang Q, Gao M, Wu W, Shao Y, Li H, Kong X, Liu S (2015) Serotype shift of a 793/B genotype infectious bronchitis coronavirus by natural recombination. Infect Genet Evol J Mol Epidemiol Evol Genet Infect Dis 32:377-387. doi:10.1016/j.meegid.2015.03.034

Zhang Y, Wang HN, Wang T, Fan WQ, Zhang AY, Wei K, Tian GB, Yang X (2010) Complete genome sequence and recombination analysis of infectious bronchitis virus attenuated vaccine strain H120. Virus Genes 41(3):377-388. doi:10.1007/s11262-010-0517-0

Zhao F, Zou N, Wang F, Guo M, Liu P, Wen X, Cao S, Huang Y (2013) Analysis of a QX-like avian infectious bronchitis virus genome identified recombination in the region containing the ORF $5 \mathrm{a}$, ORF 5b, and nucleocapsid protein gene sequences. Virus Genes 46(3):454-464. doi:10.1007/s11262-013-0884-4 
Zhou J, Yu L, Hong J (1998) Isolation, identification and pathogenicity of virus causing proventricular-type infectious bronchitis. Chi J Anim Poult Infect Dis 20:62-65

Ziegler AF, Ladman BS, Dunn PA, Schneider A, Davison S, Miller PG, Lu H, Weinstock D, Salem M, Eckroade RJ, Gelb J Jr (2002) Nephropathogenic infectious bronchitis in Pennsylvania chickens 1997-2000. Avian Dis 46(4):847-858. doi:10.1637/0005-2086(2002)046[0847:nibip c]2.0.co;2

Zulperi ZM, Omar AR, Arshad SS (2009) Sequence and phylogenetic analysis of S1, S2, M, and $\mathrm{N}$ genes of infectious bronchitis virus isolates from Malaysia. Virus Genes 38(3):383-391. doi:10.1007/s11262-009-0337-2

Zuniga S, Cruz JL, Sola I, Mateos-Gomez PA, Palacio L, Enjuanes L (2010) Coronavirus nucleocapsid protein facilitates template switching and is required for efficient transcription. J Virol 84(4):2169-2175. doi:10.1128/jvi.02011-09 